\title{
Identification of Pathogenicity Groups and Pathogenic Molecular Characterization of Fusarium oxysporum f. sp. sesami in China
}

\author{
Yinghui Duan, Wenwen Qu, Shuxian Chang, Chun Li, Fangfang Xu, Ming Ju, Ruihong Zhao, Huili Wang, \\ Haiyang Zhang, ${ }^{\dagger}$ and Hongmei Miao ${ }^{\dagger}$
}

Henan Sesame Research Center, Henan Academy of Agricultural Sciences, Zhengzhou, Henan, 450002, P. R. China

Accepted for publication 12 February 2020.

\begin{abstract}
Fusarium oxysporum f. sp. sesami is an extremely destructive pathogen, causing sesame Fusarium wilt disease worldwide. To clarify the pathogenicity and the genetic characters of $F$. oxysporum f. sp. sesami, we systematically investigated $69 \mathrm{~F}$. oxysporum isolates collected from major sesame-growing areas in China. Among these isolates, 54 isolates were pathogenic and 15 were nonpathogenic according to pathogenicity testing on sesame seedlings. For the pathogenic isolates, three $F$. oxysporum f. sp. sesami pathogenicity groups were defined based on the three differential sesame hosts for the first time. A translation elongation factor $1 \alpha$ gene tree was constructed to determine the genetic diversity of the $F$. oxysporum isolates but could not separate $F$. oxysporum f. sp. sesami isolates from the nonpathogenic isolates and other $F$. oxysporum formae speciales. Ten secreted-in-xylem (SIX) genes (one family of effectors) were identified in $F$. oxysporum f. sp. sesami isolates by a search with the
\end{abstract}

ABSTRAC genome data, and were subsequently screened in the $69 \mathrm{~F}$. oxysporum isolates. Compared with the SIX gene profiles in other $F$. oxysporum formae speciales, the presence and sequence variations of the SIX gene homologs directly correlated with the specific pathogenicity of F. oxysporum f. sp. sesami toward sesame. Furthermore, eight of these F. oxysporum f. sp. sesami SIX genes were significantly expressed in sesame plants as infection of the $F$. oxysporum f. sp. sesami isolate. These findings have important significance for understanding the pathogenic basis of $F$. oxysporum f. sp. sesami isolates, and will contribute to improve the diagnostics to effectively control Fusarium wilt disease in sesame.

Keywords: Fusarium oxysporum, Fusarium wilt, pathogenicity, secretedin-xylem, sesame
Sesame (Sesamum indicum L.) is one of the oldest oilseed crops and is widely cultivated in tropical and subtropical regions of Asia, Africa, and South America (Ashri 1998). Sesame production is seriously threatened by Fusarium wilt disease caused by Fusarium oxysporum f. sp. sesami, which was first found in the United States (Armstrong and Armstrong 1950) and was subsequently reported in China, Korean, Egypt, India, Sudan, and other main sesame production countries (Cho and Choi 1987; Li 1989; Verma et al. 2005). In China, F. oxysporum f. sp. sesami has been spread in most sesame-growing areas. The fungus commonly infects the roots of sesame plants, causing damping-off at the seedling stage, leaf chlorosis and abscission, stem necrosis, internal vascular browning, and eventually whole-plant wilting and death at the adult stage (Li et al. 2012; Su et al. 2012). Recently, a number of $F$. oxysporum f. sp. sesami isolates have been identified from wilted sesame plants and their morphological and pathogenic characteristics were further described (Li et al. 2012; Qiu et al. 2014; Su et al. 2012). However, only a single study has attempted to analyze the genetic diversity of $F$. oxysporum $\mathrm{f}$. sp. sesami isolates by

${ }^{\dagger}$ Corresponding authors: H. Zhang; zhanghaiyang@zzu.edu.cn; and H. Miao; miaohongmeichina@yahoo.com

Funding: Key Laboratory of Specific Oilseed Crops Genomics of Henan Province, the earmarked fund for China Agriculture Research System (CARS-14), International Cooperation and Exchanges Project of Henan Province (182102410040), ScienceTechnology Foundation for Outstanding Youth Scientists of Henan Academy of Agricultural Sciences (2018YQ26), the Plan for Scientific Innovation Talent of Henan Province (184200510002), the Distinguished Professor Program of Institutions of Higher Learning in Henan Province (DPPIHL2017), and the Innovation Scientists and Technicians Troop Construction Projects of Henan Province (ISTTCPHP2016).

*The $e$-Xtra logo stands for "electronic extra" and indicates that two supplementary figures and three supplementary tables are published online.

The author(s) declare no conflict of interest.

(c) 2020 The American Phytopathological Society an amplified fragment length polymorphism (AFLP) method, which showed an ambiguous correlation between molecular characteristic and pathogenicity ( $\mathrm{Li}$ et al. 2012). Thus far, a study on pathogenic differentiation, genetic diversity, and pathogenic basis of $F$. oxysporum f. sp. sesami isolates is not yet available.

F. oxysporum is well known as a ubiquitous soilborne plant pathogen that infects a wide range of plant hosts worldwide and always causes significant economic losses (Gordon and Martyn 1997; Michielse and Rep 2009). As a species complex, $F$. oxysporum comprises a diversity of morphologically indistinguishable nonpathogenic and pathogenic isolates (Snyder and Smith 1981). Conventionally, pathogenic isolates are assigned to intraspecific groups designated as formae speciales based on their host specificity (Snyder and Hansen 1940). Furthermore, several formae speciales can be subdivided into races based on their pathogenic specificity to different genotypes, lines, or cultivars of the same host species (Armstrong and Armstrong 1981).

To understand the pathogenic differentiation and genetic diversity in the $F$. oxysporum species complex (FOSC), numerous phylogenetic studies have been carried out using standard molecular approaches such as DNA fingerprinting by AFLP, restriction fragment length polymorphism, and random amplified polymorphic DNA; and locus genotyping based on sequences of internal transcribed spacer (ITS), intergenic spacer, and housekeeping genes, including translation elongation factor $1 \alpha(E F-1 a), \beta$-tubulin (Tub), RNA polymerase II, and so on (Baayen et al. 2000; Epstein et al. 2017; Lievens et al. 2008; Recorbet et al. 2003; Taylor et al. 2016). These studies revealed that the FOSC, including both phytopathogenic and clinical isolates, could be divided into four evolutionary clades (O'Donnell et al. 2004). Furthermore, the phylogenetic classification was attempted as the molecular method for identification of pathogenic $F$. oxysporum isolates, which was classically based on pathogenicity testing (Lievens et al. 2008). However, standard molecular approaches have not been successful in distinguishing between pathogenic and nonpathogenic isolates or between different formae speciales (Taylor et al. 2016). 
The genetic basis of pathogenicity in the FOSC has been found to involve specific virulence genes, which are required for virulence in host plants (Hogenhout et al. 2009). Recently, a number of putative effector genes were found to localize on the accessory lineage-specific chromosomes in F. oxysporum f. sp. lycopersici (Ma et al. 2010). Among them, 14 effector genes were identified and designated as secreted-in-xylem (SIX) genes. These genes encode small, cysteine-rich proteins, and are secreted into the xylem sap during infection of tomato plants (Houterman et al. 2007; Lievens et al. 2009; Rep and Kistler 2010; Rep et al. 2004; Schmidt et al. 2013). Moreover, five F. oxysporum f. sp. lycopersici SIX genes-SIX1 (Avr3), SIX3 (Avr2), SIX4 (Avr1), SIX5, and SIX6-were found to contribute directly to host-specific pathogenicity (Gawehns et al. 2014; Houterman et al. 2009; Ma et al. 2015; Niu et al. 2016; Rep et al. 2004), while $S I X 1, S I X 3$, and SIX4 were also recognized as avirulence genes by corresponding resistance genes $I-3, I-2$, and $I$ in tomato (Houterman et al. 2009; Ma et al. 2015; Rep et al. 2004; Takken and Rep 2010). At present, a large number of homologs of F. oxysporum f. sp. lycopersici SIX genes have been subsequently detected in other $F$. oxysporum formae speciales, including betae, canariensis, cepae, conglutinans, cubense, dianthi, fragariae, lilii, lycopersici, medicaginis, melonis, niveum, passiflorae, phaseoli, physali, pisi, raphani, vasinfectum, and zingiberi (Chakrabarti et al. 2011; Covey et al. 2014; Czislowski et al. 2018; Fraser-Smith et al. 2014; Laurence et al. 2015; Lievens et al. 2009; Simbaqueba et al. 2018; Taylor et al. 2016; Thatcher et al. 2012; Williams et al. 2016). These homologs of SIX genes commonly form a particular combination within individual $F$. oxysporum formae speciales or races (Chakrabarti et al. 2011; Czislowski et al. 2018; Lievens et al. 2009). Several studies have also demonstrated that the presence and sequence variations of $S I X$ genes could be used as ideal loci for pathogenicity-based molecular diagnostics to distinguish between F. oxysporum formae speciales or races (Chakrabarti et al. 2011; Fraser-Smith et al. 2014; Lievens et al. 2009).

In this study, we systematically investigated the pathogenicity of $69 \mathrm{~F}$. oxysporum isolates collected from major sesame-growing areas in China, and subdivided them into three pathogenicity groups based on the three differential sesame hosts with different genetic backgrounds of resistance to Fusarium wilt, which were selected from more than 500 sesame germplasm accessions worldwide using resistance evaluation techniques (Miao et al. 2019; Qiu et al. 2014). To further explore the relationship between the pathogenicity and genetic diversity of $F$. oxysporum isolates from sesame, molecular characterization of $E F-1 a$ and several SIX genes was determined. Particularly, the homologs of 10 SIX genes were first identified in $F$. oxysporum f. sp. sesami isolates. The presence and sequence variations of these $S I X$ gene homologs were demonstrated to correlate with specific pathogenicity of $F$. oxysporum f. sp. sesami toward sesame. The results revealed the availability of SIX genes for reliable discrimination of F. oxysporum f. sp. sesami isolates from nonpathogenic isolates and other formae speciales.

\section{MATERIALS AND METHODS}

Collection of Fusarium isolates. A large number of wilted sesame plants were collected from major sesame-growing areas in China between 2007 and 2011. The Fusarium isolates were separated and purified using the method described by Su et al. (2012). A small section, 2 to $3 \mathrm{~cm}$ in length, was cut from the infected tissues and surface sterilized in $70 \%$ ethanol for 1 min followed by $1.25 \% \mathrm{NaClO}$ for $10 \mathrm{~min}$, then rinsed in sterile distilled water three times. The vascular tissue were removed from the sterilized section and placed on potato dextrose agar (PDA) medium with streptomycin at $100 \mu \mathrm{g} / \mathrm{ml}$, and incubated for 3 to 4 days at $28^{\circ} \mathrm{C}$. After the morphological characteristics of Fusarium-like colonies, hyphae, and microconidia were observed, the isolates were purified by single-spore isolation, and maintained on PDA plates. A representative subset of 69 F. oxysporum isolates and three $F$. solani isolates from sesame was selected for subsequent pathogenicity testing, gene amplification, and phylogenetic analysis (Table 1).

Pathogenicity testing. The aforementioned 72 Fusarium isolates were assessed for their pathogenicity toward sesame seedlings as described by Qiu et al. (2014). Each isolate was cultured on PDA for 5 to 7 days at $28^{\circ} \mathrm{C}$. One agar plug $(5 \mathrm{~mm})$ from the colony edge was placed in a culture flask containing potato dextrose broth (PDB) and incubated at $28^{\circ} \mathrm{C}$ and $120 \mathrm{rpm}$ on a rotary shaker for 4 days. Microconidial suspensions were filtered through three layers of sterilized gauze and centrifuged at 5,000 rpm for $8 \mathrm{~min}$. The microconidial pellet was washed three times in sterile distilled water to remove the PDB. Then, the spores were resuspended to a final concentration of $4 \times 10^{6}$ conidia/ml for inoculation.

Three sesame cultivars (Yuzhi 11, Ji 9014, and HJ16) were chosen for the pathogenicity evaluation. Three independent replicates for each variety were set for each treatment. Ten seeds for each sesame cultivar were grown in $12-\mathrm{cm}$-diameter plastic pots with infected medium containing a mixture of conidial suspensions, sterilized vermiculite, and soil (1:3:3 [ $\mathrm{vol} / \mathrm{vol} / \mathrm{vol}])$. The final concentration of $F$. oxysporum $\mathrm{f}$. sp. sesami isolates was set at 5 to $7 \times 10^{5}$ conidia $/ \mathrm{ml}$. Inoculated plants were positioned in growth chambers with day and night of 15 and $9 \mathrm{~h}$ at 28 and $23^{\circ} \mathrm{C}$, respectively, and $70 \%$ relative humidity. The 10 -fold-diluted liquid Murashige-Skoog medium was watered regularly for seedling growth. Sterile distilled water was used as control.

Fusarium wilt disease symptoms of each treatment were recorded after 28 days inoculation. The symptoms of roots, stems, and leaves were scored using a categorical disease severity scale, where $0=$ no visible symptoms, 1 = slight wilting of seedling, $2=$ severe browning of principal root, wilting of plant, and slow growth, and 3 = death of the whole plant. The disease index (DI) data were further calculated using the formula described by Qiu et al. (2014). The significant difference in pathogenicity between Fusarium isolates was analyzed using analysis of variance in SAS software (SAS Institute Inc.). The pathogenicity levels of Fusarium isolates were also evaluated using the grade scale as follows: $0 \leq \mathrm{DI} \leq 20=$ nonpathogenicity or weak pathogenicity, $20<\mathrm{DI} \leq 50=$ moderate pathogenicity, and $50<$ DI $\leq 100=$ high pathogenicity.

DNA extraction. The mycelia of each Fusarium isolate were collected on three layers of sterilized gauze, and the excess liquid was removed using filter papers. Immediately, the mycelia were frozen in liquid nitrogen and stored at $-80^{\circ} \mathrm{C}$ for genomic DNA extraction. Genomic DNA was extracted using a Qiagen DNeasy Plant Minikit (Qiagen) according to the manufacturer's instructions.

PCR amplification of $\boldsymbol{E F}$-1 $\boldsymbol{a}$ gene. The $E F-1 a$ gene was used to distinguish taxa at the infraspecies level within the 69 $F$. oxysporum isolates from sesame. The $E F-1 a$ gene sequences were amplified by PCR with a primer pair designed using Primer Premier 5.0 (PREMIER Biosoft) (Table 2). PCRs were set up in a 20- $\mu 1$ mixture containing $1 \times$ PCR Buffer, $0.1 \mathrm{mM}$ dNTPs, $0.2 \mu \mathrm{M}$ of each primer, 1.0 $\mathrm{U}$ of Taq polymerase (Vazyme), and approximately $50 \mathrm{ng}$ of DNA. PCR amplifications were performed on an Eppendorf Mastercycler (Eppendorf) under the following conditions: $95^{\circ} \mathrm{C}$ for $2 \mathrm{~min} ; 35$ cycles of $95^{\circ} \mathrm{C}$ for $20 \mathrm{~s}, 55^{\circ} \mathrm{C}$ for $30 \mathrm{~s}$, and $72^{\circ} \mathrm{C}$ for $1 \mathrm{~min}$; with a final 8 -min extension at $72^{\circ} \mathrm{C}$. The products were visualized by electrophoresis on $1 \%$ agarose gel using a Gel Doc XR+ Imaging System (Bio-Rad) and purified using a SanPrep Column DNA Gel Extraction Kit (Sangon Biotech), then sequenced on an ABI 3730 XL DNA Analyzer (Applied Biosystem) by forward and reverse primers. The $E F-1 a$ gene sequences in the $69 \mathrm{~F}$. oxysporum isolates were deposited into GenBank with the accessions MN417138 to MN417206. Additionally, $E F-1 a$ gene sequences in other species were obtained from the publicly available genomes of $F$. oxysporum (https:// www.ncbi.nlm.nih.gov/genome/genomes/707) and the NCBI nucleotide database through a BLAST search on a reference sequence in F. oxysporum f. sp. sesami isolate FS08027 (Supplementary Table S1). 
TABLE 1. Fusarium isolates used for pathogenicity testing, phylogenetic analysis, and identification of secreted-in-xylem genes in this study

\begin{tabular}{|c|c|c|c|}
\hline Fusarium spp. & Isolate code & Collection location & Year isolated \\
\hline $\begin{array}{l}\text { Fusarium } \\
\text { oxysporum }\end{array}$ & FS09033 & Anqing, Anhui & 2009 \\
\hline F. oxysporum & FS09035 & Chuzhou, Anhui & 2009 \\
\hline F. oxysporum & FS09037 & Fuyang, Anhui, site 1 & 2009 \\
\hline F. oxysporum & FS09038 & Fuyang, Anhui, site 2 & 2009 \\
\hline F. oxysporum & FS09095 & Fuyang, Anhui, site 3 & 2009 \\
\hline F. oxysporum & FS11608 & Fuyang, Anhui, site 4 & 2011 \\
\hline F. oxysporum & FS10176b & Hefei, Anhui & 2010 \\
\hline F. oxysporum & FS10133 & Xuancheng, Anhui, site 1 & 2010 \\
\hline F. oxysporum & FS10175 & Xuancheng, Anhui, site 2 & 2010 \\
\hline F. oxysporum & FS10134 & Hengshui, Hebei & 2010 \\
\hline F. oxysporum & FS09060 & Shijiazhuang, Hebei, site 1 & 2009 \\
\hline F. oxysporum & FS10198 & Shijiazhuang, Hebei, site 2 & 2010 \\
\hline F. oxysporum & FS11649 & Shijiazhuang, Hebei, site 3 & 2011 \\
\hline F. oxysporum & FS07021 & Pingdingshan, Henan & 2007 \\
\hline F. oxysporum & FS07024 & Xuchang, Henan & 2007 \\
\hline F. oxysporum & FS08027 & Luohe, Henan & 2008 \\
\hline F. oxysporum & FS09086 & Jiaozuo, Henan & 2009 \\
\hline F. oxysporum & FS09076 & Luoyang, Henan, site 1 & 2009 \\
\hline F. oxysporum & FS09078 & Luoyang, Henan, site 2 & 2009 \\
\hline F. oxysporum & FS10112 & Luoyang, Henan, site 3 & 2010 \\
\hline F. oxysporum & FS11597a & Luoyang, Henan, site 4 & 2011 \\
\hline F. oxysporum & FS07008 & Nanyang, Henan, site 1 & 2007 \\
\hline F. oxysporum & FS09025 & Nanyang, Henan, site 2 & 2009 \\
\hline F. oxysporum & FS10211 & Nanyang, Henan, site 3 & 2010 \\
\hline F. oxysporum & FS09069 & Xinxiang, Henan, site 1 & 2009 \\
\hline F. oxysporum & FS09100 & Xinxiang, Henan, site 2 & 2009 \\
\hline F. oxysporum & FS09077 & Zhengzhou, Henan & 2009 \\
\hline F. oxysporum & FS09046 & Zhoukou, Henan & 2009 \\
\hline F. oxysporum & FS09012 & Zhumadian, Henan, site 1 & 2009 \\
\hline F. oxysporum & FS10012 & Zhumadian, Henan, site 2 & 2010 \\
\hline F. oxysporum & FS11603b & Zhumadian, Henan, site 3 & 2011 \\
\hline F. oxysporum & FS11641 & Sanmenxia, Henan, site 1 & 2011 \\
\hline F. oxysporum & FS11719a & Sanmenxia, Henan, site 2 & 2011 \\
\hline F. oxysporum & FS11719b1 & Sanmenxia, Henan, site 2 & 2011 \\
\hline F. oxysporum & FS08042 & Xiangyang, Hubei, site 1 & 2008 \\
\hline F. oxysporum & FS09096 & Xiangyang, Hubei, site 2 & 2009 \\
\hline F. oxysporum & FS10040 & Xiangyang, Hubei, site 3 & 2010 \\
\hline F. oxysporum & FS1 $1454 a$ & Xiangyang, Hubei, site 3 & 2011 \\
\hline F. oxysporum & FS11473a & Xiangyang, Hubei, site 4 & 2011 \\
\hline F. oxysporum & FS11614 & Xiangyang, Hubei, site 5 & 2011 \\
\hline F. oxysporum & FS10099 & Huanggang, Hubei & 2010 \\
\hline F. oxysporum & FS09016 & Harbin, Heilongjiang & 2009 \\
\hline F. oxysporum & FS09017 & Baicheng, Jilin, site 1 & 2009 \\
\hline F. oxysporum & FS09018 & Baicheng, Jilin, site 2 & 2009 \\
\hline F. oxysporum & FS10218 & Shuangliao, Jilin & 2010 \\
\hline F. oxysporum & FS10216 & Songyuan, Jilin & 2010 \\
\hline F. oxysporum & FS10173a2 & Huaian, Jiangsu & 2010 \\
\hline F. oxysporum & FS10090a & Jiangxi & 2010 \\
\hline F. oxysporum & FS10184b1 & Nanchang, Jiangxi & 2010 \\
\hline F. oxysporum & FS10224 & Chaoyang, Liangning & 2010 \\
\hline F. oxysporum & FS10228 & Chaoyang, Liangning & 2010 \\
\hline F. oxysporum & FS09051 & Liaoyang, Liaoning, Site 1 & 2009 \\
\hline F. oxysporum & FS10001 & Liaoyang, Liaoning, Site 2 & 2010 \\
\hline F. oxysporum & FS10008 & Liaoyang, Liaoning, Site 2 & 2010 \\
\hline F. oxysporum & FS10195 & Shenyang, Liaoning & 2010 \\
\hline F. oxysporum & FS10053 & Fenyang, Shanxi, site 1 & 2010 \\
\hline F. oxysporum & FS10201 & Fenyang, Shanxi, site 1 & 2010 \\
\hline F. oxysporum & FS11718a & Fenyang, Shanxi, site 2 & 2011 \\
\hline F. oxysporum & FS10044 & Jinzhong, Shanxi & 2010 \\
\hline F. oxysporum & FS10047 & Jinzhong, Shanxi & 2010 \\
\hline F. oxysporum & FS11458 & Ankang, Shaanxi, site 1 & 2011 \\
\hline F. oxysporum & FS11476a & Ankang, Shaanxi, site2 & 2011 \\
\hline F. oxysporum & FS11527 & Ankang, Shaanxi, site3 & 2011 \\
\hline F. oxysporum & FS11584a & Ankang, Shaanxi, site4 & 2011 \\
\hline F. oxysporum & FS11470 & Hanzhong, Shaanxi & 2011 \\
\hline F. oxysporum & FS11509 & Hanzhong, Shaanxi & 2011 \\
\hline F. oxysporum & FS11416 & Shangluo, Shaanxi & 2011 \\
\hline F. oxysporum & FS11710b & Weinan, Shaanxi & 2011 \\
\hline F. oxysporum & FS11702 & Yulin, Shaanxi & 2011 \\
\hline F. solani & FS07029 & Pingdingshan, Henan & 2007 \\
\hline F. solani & FS08030 & Luohe, Henan & 2008 \\
\hline F. solani & FS09040 & Shangqiu, Henan & 2009 \\
\hline
\end{tabular}

Identification of $S I X$ genes. The $S I X$ genes were identified in F. oxysporum f. sp. sesami by a BLAST search with E-value $\leq 1 \mathrm{E}-10$ from our preliminary genome assemblies of the isolates FS08027, FS09095, and FS10175 (unpublished data) based on the reference sequences of SIX1 to -14 from $F$. oxysporum f. sp. lycopersici isolates 4287, MN25, and BFOL-51 (Lievens et al. 2009; Schmidt et al. 2013). All F. oxysporum f. sp. sesami SIX genes were further screened in the $69 \mathrm{~F}$. oxysporum isolates and $3 F$. solani isolates using PCR amplification. The specific primers of $F$. oxysporum f. sp. sesami SIX genes were designed (Table 2), and PCRs were set up as described above. PCR amplification was performed with standard conditions as follows: $95^{\circ} \mathrm{C}$ for $2 \mathrm{~min} ; 35$ cycles of $95^{\circ} \mathrm{C}$ for $20 \mathrm{~s}, 55$ to $61^{\circ} \mathrm{C}$ annealing (see Table 2 for temperatures) for $30 \mathrm{~s}$, and $72^{\circ} \mathrm{C}$ for $1 \mathrm{~min}$; with a final cycle of $8 \mathrm{~min}$ at $72^{\circ} \mathrm{C}$. The amplicons were visualized, purified, and sequenced as described above. The GenBank accessions MN417207 to MN417222 were provided for the SIX1 to -14 gene sequences in the Fusarium isolates from sesame. The homologs of SIX genes were also searched in other species by blasting the reference sequences of $F$. oxysporum f. sp. lycopersici SIX1 to -14 against the aforementioned nucleotide datasets (Supplementary Table S1). The sequences of the SIX genes in both $F$. oxysporum f. sp. sesami and the other species were aligned using DNAMAN 6 software (Lynnon Corporation), and the sequence similarities of SIX genes were outputted by the observed divergence method based on the sequence alignments.

Phylogenetic analysis. Phylogenetic analyses were performed on the EF-1 $a$ and SIX gene datasets. The sequences were aligned by the Muscle method, and the maximum-likelihood (ML) trees were constructed using MEGA 5.2 software (https://www.megasoftware. net/) with the computed most appropriate models: Kimura twoparameter for EF-1a, SIX6, SIX11, and SIX14; Kimura two-parameter plus invariant sites for $S I X 1$ and $S I X 9$; Kimura two-parameter plus $\gamma$ distribution for SIX7, SIX8, and SIX13; Jukes-Cantor for SIX3; and Jukes-Cantor plus $\gamma$ distribution for SIX10. For the EF-1a tree, the $F$. foetens isolate NRRL31841 was used as the outgroup taxon (Schroers et al. 2004). Branches were tested for the inferred tree by bootstrap analysis on 1,000 random trees.

Infection treatment and expression profile assay of F. oxysporum f. sp. sesami SIX genes. The sesame cultivar Yuzhi 11, susceptible to isolate FS08027, was used in the infection treatment. Seed were grown in pots with sterilized vermiculite in growth chambers, as described above. Four-week-old seedlings with two pairs of true leaves were gently pulled out of the potting substrate, and the roots were carefully washed in water. The root mass was dipped into a microconidial suspension of $4 \times 10^{6}$ conidia/ $\mathrm{ml}$ for $10 \mathrm{~min}$; then, the seedlings were planted in pots with sterilized vermiculite. The roots were sampled at 12, 24, 48, 72, 120 , and $168 \mathrm{~h}$ postinoculation (hpi). The microconidia and mycelia of the FS08027 strain were also collected as described above. Three independent replicates were carried out in the experiment. All samples were frozen in liquid nitrogen and stored at $-80^{\circ} \mathrm{C}$ for total RNA extraction.

Total RNA was extracted from samples using RNAiso Plus Reagent (TaKaRa), and genomic DNA was removed by DNase I treatment. First-strand cDNA was synthesized using a RevertAid First-Strand cDNA Synthesis Kit (Thermo Scientific) according to the manufacturer's instructions. Primer pairs of $F$. oxysporum f. sp. sesami SIX genes were designed using Primer Premier 5.0 for Realtime PCR detection. Real-time PCR was performed on a Mastercycler ep realplex (Eppendorf), with the PCR mixture in a total volume of $20 \mu \mathrm{l}$ containing $10 \mu \mathrm{l}$ of FastStart Essential DNA Green Master (Roche), $2.0 \mu \mathrm{l}$ of fivefold-diluted first-strand cDNA, and $0.2 \mu \mathrm{M}$ each primer. The cycling conditions were as follows: $95^{\circ} \mathrm{C}$ for $10 \mathrm{~min}$ and 40 cycles of $95^{\circ} \mathrm{C}$ for $15 \mathrm{~s}, 56$ to $60^{\circ} \mathrm{C}$ for $20 \mathrm{~s}$ (Table 2), and $72^{\circ} \mathrm{C}$ for $15 \mathrm{~s}$. The specific product of each gene was confirmed using the melt-curve analysis. The transcriptional level of $F$. oxysporum f. sp. sesami SIX genes was analyzed against the F. oxysporum f. sp. sesami Tub gene using the $2^{-\Delta C T}$ method (Pfaffl 
2001). The significant difference between transcriptional levels in microconidia, mycelia, and infected roots was analyzed using Student's $t$ test in SPSS 16.0 (SPSS Inc.).

\section{RESULTS}

Pathogenicity testing and classification of pathogenicity group of $\boldsymbol{F}$. oxysporum f. sp. sesami isolates. On the basis of the geographical locations, morphological characteristics, and ITS sequences, $69 F$. oxysporum isolates from sesame were selected for pathogenicity testing. Meanwhile, three $F$. solani isolates originally separated from diseased sesame plants were also evaluated for their ability to cause wilt disease. In the sesame seedling test, significantly different pathogenicity was observed in the F. oxysporum isolates on three sesame cultivars (Yuzhi 11, Ji 9014, and HJ16) (Fig. 1). Of the 69 F. oxysporum isolates, 50 isolates caused significant seedling wilt on all three sesame cultivars; 1 isolate (FS09095) was highly pathogenic to Ji 9014 and HJ16 but presented nonpathogenicity or weak pathogenicity to Yuzhi 11; and 3 isolates (FS09060, FS09069, and FS10175) were specifically pathogenic to HJ16. Therefore, in total, $54 \mathrm{~F}$. oxysporum isolates could be assigned to $\mathrm{f}$. sp. sesami. In addition, the remaining $15 \mathrm{~F}$. oxysporum isolates and 3 $F$. solani isolates did not cause significant disease symptoms on sesame.
Based on the different pathogenicity toward three sesame cultivars, the $F$. oxysporum f. sp. sesami isolates were subdivided into three pathogenicity groups. $F$. oxysporum f. sp. sesami pathogenicity group 1 was defined for the isolates with pathogenicity specifically on HJ16, F. oxysporum f. sp. sesami pathogenicity group 2 was pathogenic to $\mathrm{Ji} 9014$ and HJ16 but nonpathogenic to Yuzhi 11, and F. oxysporum f. sp. sesami pathogenicity group 3 was highly pathogenic to all three cultivars (Table 3). Surprisingly, 50 of the 54 F. oxysporum f. sp. sesami isolates were assigned to $F$. oxysporum f. sp. sesami pathogenicity group 3 , which was distributed across almost all the collection locations in China between 2007 and 2011. In contrast, the three isolates of pathogenicity group 1 were collected from Hebei, Henan, and Anhui Provinces in 2009 and 2010, and the only isolate of pathogenicity group 2 was collected from Anhui Province in 2009.

Phylogenetic relationship of $F$. oxysporum f. sp. sesami isolates. To determine the phylogenetic relationship of $F$. oxysporum f. sp. sesami and nonpathogens from sesame, the ML tree was constructed based on EF-1a sequences, including those in $F$. oxysporum isolates from sesame and other plants and nonpathogenic isolate Fo47. The phylogenetic analyses showed that the FOSC isolates in this study were divided into four clades, and the 69 isolates from sesame were placed in clades I, III, and IV (Fig. 2). Clade I covered all 54 pathogenic isolates in F. oxysporum

TABLE 2. Primer pairs used for the amplification and quantitative detection of target sequences (genes) in this study

\begin{tabular}{|c|c|c|c|c|}
\hline Target $^{\mathrm{a}}$ & Primers & Sequences (forward primer/reverse primer, $5^{\prime}-3^{\prime}$ ) & Size $(b p)^{b}$ & $\mathrm{~T}\left({ }^{\circ} \mathrm{C}\right)^{\mathrm{c}}$ \\
\hline \multicolumn{5}{|l|}{$\mathrm{PCR}^{\mathrm{d}}$} \\
\hline$E F-1 a$ & $\mathrm{EF}-\mathrm{F} / \mathrm{EF}-\mathrm{R}$ & ATGGGTAAGGAGGACAAGAC/GCCATCCTTGGAGATACCAGC & $\sim 784$ & 55 \\
\hline SIX1 & SIX1-F/SIX1-R & GCTACCATTATTTACAATCCCCATC/CGAAGCCGATAGTAAATGAGTGAC & 1,062 & 60 \\
\hline SIX3 & SIX3-F/SIX3-R & ATGCGTTTCCTTCTGCTTATCG/TTCGCTTGGGATTCCAGACAT & 559 & 61 \\
\hline SIX6 & SIX6-F/SIX6-R & AACTTCAGCCCAATCTTCACG/CATCCCTACTGGGCTCAGAACT & 771 & 59 \\
\hline SIX7 & SIX7-F/SIX7-R & CAGAGTCAGTTATGTGGCACAAG/GACTTGCTACTAACTCTGCTGTGTT & 705 & 57 \\
\hline SIX8al & SIX8a1-F/SIX8a1-R & ACCTGTATCAAAAGAACAGCTCTG/TATCCCTATCGGGCCTGAT & 778 & 56 \\
\hline SIX $8 a 2$ & SIX8a2-F/SIX8a2-R & GCCGATTTTATTTACAGTATGTTAC/ACACAACACACAACAATAGCTACTA & 814 & 55 \\
\hline SIX8a3 & SIX8a3-F/SIX8a3-R & CCCGTATCAAAAGAACAGCTCTT/CCTTATCCCTATCAGGCCTAAC & 784 & 57 \\
\hline SIX $8 a 4$ & SIX8a4-F/SIX8a4-R & CCCGTATCAAAAGAACAGCTCTC/TTATCCCTATCGGGCCTCAT & 1,733 & 58 \\
\hline SIX $8 a 5$ & SIX8a1-F/SIX8a1-R & ACCTGTATCAAAAGAACAGCTCTG/TATCCCTATCGGGCCTGAT & 772 & 56 \\
\hline$S I X 8 b$ & SIX8b-F/SIX8b-R & GCTTTTAAGAGAGATTTAAGCGGG/GATGGGACTGCCTATGTGCC & 735 & 60 \\
\hline SIX9 & SIX9-F/SIX9-R & GAGCGCTGATCACAGCTTTTAG/TTAATTGACGGTGCATTGTCC & 676 & 58 \\
\hline SIX10 & SIX10-F/SIX10-R & ATACCAAGCGATAACCCGTCT/TCAATAAAGAGGGGGATGGTAG & 657 & 58 \\
\hline SIX11 & SIX11-F/SIX11-R & ATGATGTTCTCAAAGGCCATCTC/TCAAATGCAGGGTCTATTGAGAAT & 336 & 60 \\
\hline SIX13 & SIX13-F/SIX13-R & CTGCCCACTATGACTCGGTTTC/CAGGATTATTTTCTGGCGTCTAG & 1,027 & 58 \\
\hline SIX14 & SIX14-F/SIX14-R & ATGCATTTCCACTATGTATTTCTTC/TATTGTCCAAGCTAACTTTAACAGC & 334 & 57 \\
\hline \multicolumn{5}{|c|}{ ( } \\
\hline SIX13a & S-SIX13a-F/S-SIX13a-R & ATGAAGATAGGTCATGCAACGC/CGTACACATGATGTATAAGGTACCAGT & 316 & 59 \\
\hline$S I X 13 b$ & S-SIX13b-F/S-SIX13b-R & TAGATGAAGATACGTCATGCAACAG/CGTACACATGATGTATGAGGTACCATA & 319 & 59 \\
\hline \multicolumn{5}{|c|}{ - } \\
\hline SIX1 & RT-SIX1-F/RT-SIX1-R & TCCTTGGGTTTGGGGCTTA/TGGGACAACATCGTCCGTC & 185 & 56 \\
\hline SIX3 & RT-SIX3-F/RT-SIX3-R & TGCGTTTCCTTCTGCTTATCG/GGAGGGTCTCTGGGTATTGTTC & 214 & 59 \\
\hline SIX6 & RT-SIX6-F/RT-SIX6-R & TCACTATGTTGATGAAGGTCCCA/GTTTTCCGTTGCTAAGGTTGC & 251 & 59 \\
\hline SIX7 & RT-SIX7-F/RT-SIX7-R & СТTTAССТССТTTTCСАTTTCG/AGAGTCCTACACCCTGAGTCCA & 208 & 57 \\
\hline SIX8al & RT-SIX8a1-F/RT-SIX8a1-R & TGGCGTTTCAGGCATATGCT/GCACGATCTGGACTACTTCCC & 168 & 58 \\
\hline SIX $8 a 2$ & RT-SIX8a2-F/RT-SIX8a2-R & GTGGCGTTTCAGGCATATCA/CACGATCTGGACTACTTCCCG & 168 & 59 \\
\hline SIX $8 a 3$ & RT-SIX8a3-F/RT-SIX8a3-R & ACGGCGTTTCAGGCATATCA/GCGATTTGGACTACCTCCGAC & 167 & 60 \\
\hline SIX8a4 & RT-SIX8a4-F/RT-SIX8a4-R & CTGCATAACAGGTGCCGGT/GCACGATTTGGACTACCTCGT & 188 & 59 \\
\hline$S I X 8 b$ & RT-SIX8b-F/RT-SIX8b-R & GGCGGTAACTGAAGTGGTGG/GATGGGACTGCCTATGTGCC & 108 & 60 \\
\hline SIX9 & RT-SIX9-F/RT-SIX9-R & CGGTTGCTACGCTGTTGATT/GTTCCGGTGCTCGTTTTTG & 213 & 58 \\
\hline SIX10 & RT-SIX10-F/RT-SIX10-R & GTGTTACCCCACTTGTTCGTTC/CTCGTAGATTAGTCTGCCGTCC & 185 & 58 \\
\hline SIX11 & RT-SIX11-F/RT-SIX11-R & CCGCCAGAATGTTATCTTGAA/GCAGGGTCTATTGAGAATGCC & 211 & 58 \\
\hline SIX13a & RT-SIX13a-F/RT-SIX13a-R & GCAGCACTACAGAGGCTCCA/GTTGCATGACCTATCTTCATCTGA & 99 & 58 \\
\hline$S I X 13 b$ & RT-SIX13b-F/RT-SIX13b-R & CCTGGTTCTCCTATTGCTTATGA/GTTGCATGACGTATCTTCATCTAC & 272 & 56 \\
\hline SIX14 & RT-SIX14-F/RT-SIX14-R & TGCCTAATGGCTCCCTGAAC/CAACAGAACCGCCGTTATCAT & 162 & 60 \\
\hline$\beta$-tubulin & FoTub-F/FoTub-R & GCCTTTCCCTCGTCTACACTT/AGTTCTTGTTCTGGACGTTGC & 239 & 57 \\
\hline
\end{tabular}

a EF-1a = translation elongation factor $1 a$ and SIX = secreted-in-xylem.

b Amplicon size.

c Annealing temperature.

d PCR amplification and sequencing.

e Specific homologs of SIX13 screening.

f Real-time reverse-transcription PCR detection. 
f. sp. sesami pathogenicity groups 1, 2, and 3 as well as the 2 nonpathogenic isolates, FS09046 and FS10184b1. Isolate FS09046 presented an $E F-1 a$ sequence identical to that of the $F$. oxysporum $\mathrm{f}$. sp. sesami isolates, which was also identical to the isolates of ff. spp. vasinfectum, niveum, and fragariae. Additionally, 1 nonpathogenic isolate, FS11476a, shared an identical EF-1a sequence with the biocontrol isolate Fo47 and was placed in clade III (Fuchs et al. 1997), while the other 12 nonpathogenic isolates from sesame were clustered in clade IV with the isolates of $\mathrm{f}$. sp. cubense race 4 isolates.

Identification of $S I X$ genes in $F$. oxysporum f. sp. sesami. The genome sequences of the three $F$. oxysporum f. sp. sesami
$16 \mathrm{HJ}$

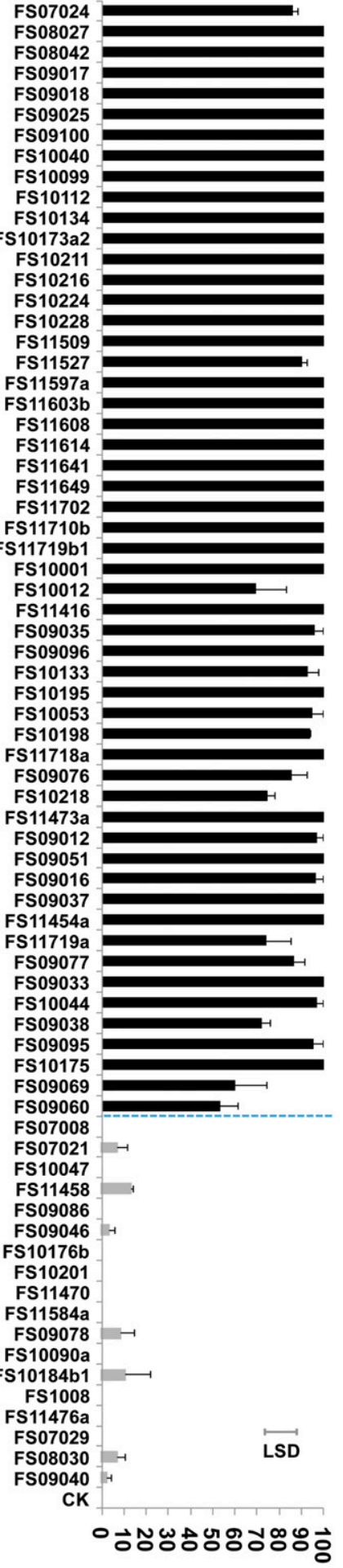

Ji 9014

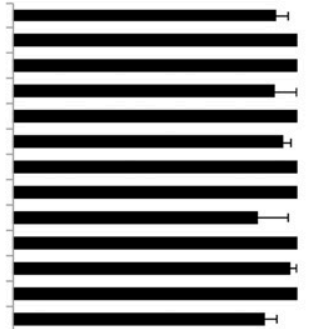

(2)
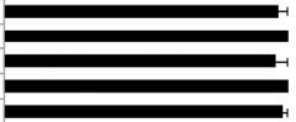

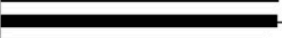

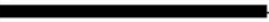

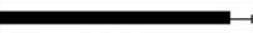

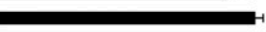

-

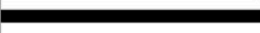

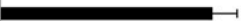

$\longrightarrow$

-

-

mararararara

(a)

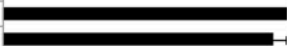

$\longrightarrow$

- arar

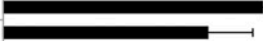

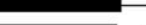

$\longrightarrow$

rararar

-

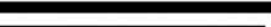

-

-

mararararara

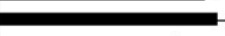

$\longrightarrow$

(2)
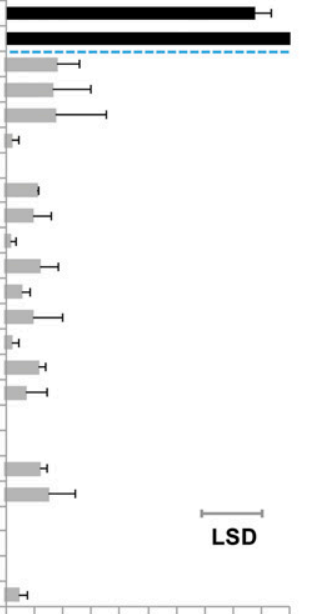

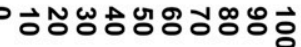

Yuzhi 11

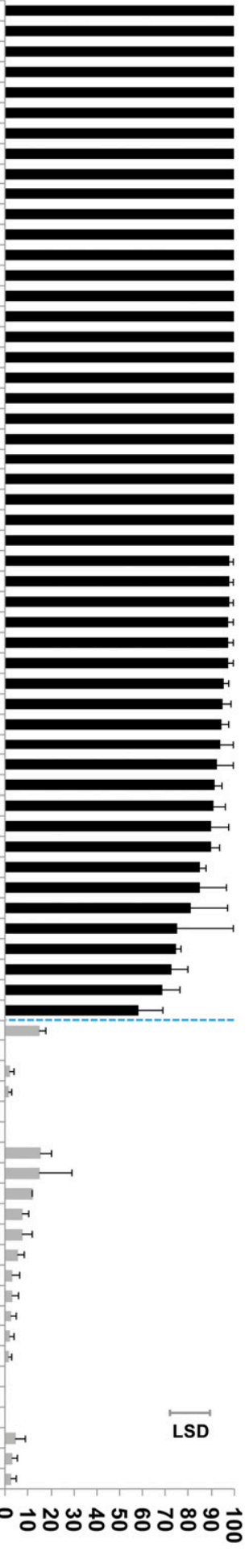

Fig. 1. Pathogenicity of 69 Fusarium oxysporum isolates and 3 F. solani isolates toward the seedlings of three sesame cultivars: Yuzhi 11, Ji 9014, and HJ16. Data on the disease index (DI) were calculated from three independent biological replications at 28 days postinoculation. Error bars indicate the standard error of the mean. The least significant difference $(\alpha=0.05)$ was analyzed using analysis of variance in SAS software. The dotted line separates the DI values into two parts, and the upper is significantly different from the uninoculated control (CK). 
isolates (FS10175, FS09095, and FS08027) were queried based on F. oxysporum f. sp. lycopersici SIX1 to -14 sequences to search for SIX genes in F. oxysporum f. sp. sesami. As a result, the homologies of $10 \mathrm{~F}$. oxysporum f. sp. lycopersici SIX genes-SIX1, SIX3, SIX6, SIX7, SIX8, SIX9, SIX10, SIX11, SIX13, and $S I X 14$-were identified in the $F$. oxysporum $\mathrm{f}$. sp. sesami isolates. Furthermore, the presence and sequence of these SIX gene homologs were verified by PCR screening in the 69 $F$. oxysporum isolates and $3 F$. solani isolates from sesame (Table 3). All 10 F. oxysporum f. sp. sesami SIX genes were present in the 3 isolates in $F$. oxysporum $\mathrm{f}$. sp. sesami pathogenicity group 1 and 29 isolates in F. oxysporum f. sp. sesami pathogenicity group 3 , and the majority of the $S I X$ genes (except one or two of the SIX1, SIX3, SIX9, SIX10, and SIX14 genes) were present in the other 21 isolates in $F$. oxysporum f. sp. sesami pathogenicity group 3 and the 1 isolate in $F$. oxysporum f. sp. sesami pathogenicity group 2. Noticeably, five $S I X$ genes (SIX6, SIX7, SIX8, SIX11, and SIX13) were identified in all $54 \mathrm{~F}$. oxysporum $\mathrm{f}$. sp. sesami isolates. In contrast, all SIX genes were absent in the 15 nonpathogenic $F$. oxysporum and $3 F$. solani isolates, with the exception of two nonpathogenic isolates, FS10090a and FS10176b, which possessed the SIX8 gene.

No polymorphisms in eight $F$. oxysporum f. sp. sesami SIX genes were individually detected either within an $F$. oxysporum $\mathrm{f}$. sp. sesami isolate or between the different $F$. oxysporum f. sp. sesami isolates, with the exception of SIX8 and SIXI3 (Table 3). The sequence variations of $S I X 8$ and $S I X 13$ were observed in a single F. oxysporum f. sp. sesami isolate, which led to the identification of five distinct SIX8 gene homologs (SIX8a1, SIX8a2, SIX8a3, SIX8a4, and SIX8b) and two SIX13 gene homologs (SIX13a and $S I X 13 b)$ (Supplementary Figs. S1 and S2). Another SIX8 gene homolog (SIX8a5) was identified in the nonpathogenic isolates FS10090a and FS10176b. Similar to other $F$. oxysporum f. sp. sesami SIX genes, each homolog of F. oxysporum f. sp. sesami SIX 8 and SIX13 had an identical sequence between the different F. oxysporum f. sp. sesami isolates.

The homologs of SIX genes were also identified from another 26 F. oxysporum formae speciales isolates and Verticillium dahliae isolate JR2 (Supplementary Table S2) (Czislowski et al. 2018). The sequence alignments generated from the coding DNA sequences of these SIX genes showed that SIX genes in F. oxysporum f. sp. sesami shared high sequence similarity to those in other formae speciales, ranging from 63.4 to $100 \%$ nucleotide identity (Supplementary Table S3). Notably, F. oxysporum f. sp. sesami SIX8a4 and SIX14 shared identical sequences with corresponding SIX genes in $F$. oxysporum $\mathrm{f}$. sp. niveum, and $F$. oxysporum $\mathrm{f}$. sp. sesami SIX 9 also had an identical sequence with the SIX 9 genes in ff. spp. vasinfectum, niveum, and raphanin and Fo5176. However,

TABLE 3. Homologs of secreted-in-xylem (SIX)1 to -14 identified in Fusarium oxysporum and F. solani isolates from sesame

\begin{tabular}{|c|c|c|c|c|c|c|c|c|c|c|c|c|c|c|c|c|c|c|}
\hline \multirow[b]{2}{*}{ Species, code ${ }^{a}$} & \multirow[b]{2}{*}{$P^{b}$} & \multicolumn{3}{|c|}{ Pathogenicity $^{\mathrm{c}}$} & \multicolumn{14}{|c|}{ SIX gene ${ }^{\mathrm{d}}$} \\
\hline & & $\mathrm{Yu}$ & $\mathrm{Ji}$ & $\mathrm{HJ}$ & 1 & 2 & 3 & 4 & 5 & 6 & 7 & $8^{e}$ & 9 & 10 & 11 & 12 & 13 & 14 \\
\hline \multicolumn{19}{|c|}{ F. oxysporum f. sp. sesame } \\
\hline FS09060 & 1 & - & - & + & + & - & + & - & - & + & + & $\mathrm{a} 1, \mathrm{a} 2, \mathrm{a} 3, \mathrm{a} 4, \mathrm{~b}$ & + & + & + & - & $a, b$ & + \\
\hline FS09069 & 1 & - & - & + & + & - & + & - & - & + & + & $\mathrm{a} 1, \mathrm{a} 2, \mathrm{a} 3, \mathrm{a} 4, \mathrm{~b}$ & + & + & + & - & $a, b$ & + \\
\hline FS10175 & 1 & - & - & + & + & - & + & - & - & + & + & $\mathrm{a} 1, \mathrm{a} 2, \mathrm{a} 3, \mathrm{a} 4, \mathrm{~b}$ & + & + & + & - & $a, b$ & + \\
\hline FS09095* & 2 & - & + & + & + & - & + & - & - & + & + & $\mathrm{a} 1, \mathrm{a} 2, \mathrm{~b}$ & + & + & + & - & $\mathrm{a}$ & - \\
\hline FS10133 & 3 & + & + & + & - & - & - & - & - & + & + & $\mathrm{a} 1, \mathrm{a} 2, \mathrm{a} 3, \mathrm{a} 4, \mathrm{~b}$ & + & + & + & - & $a, b$ & + \\
\hline FS10134 & 3 & + & + & + & - & - & - & - & - & + & + & $\mathrm{a} 1, \mathrm{a} 2, \mathrm{a} 3, \mathrm{a} 4, \mathrm{~b}$ & + & + & + & - & $a, b$ & + \\
\hline FS09017* & 3 & + & + & + & - & - & + & - & - & + & + & $\mathrm{a} 1, \mathrm{a} 2, \mathrm{a} 3, \mathrm{a} 4, \mathrm{~b}$ & + & + & + & - & $a, b$ & + \\
\hline FS09018 & 3 & + & + & + & - & - & + & - & - & + & + & $\mathrm{a} 1, \mathrm{a} 2, \mathrm{a} 3, \mathrm{a} 4, \mathrm{~b}$ & + & + & + & - & $a, b$ & + \\
\hline FS09051 & 3 & + & + & + & - & - & + & - & - & + & + & $\mathrm{a} 1, \mathrm{a} 2, \mathrm{a} 3, \mathrm{a} 4, \mathrm{~b}$ & + & + & + & - & $a, b$ & + \\
\hline FS09096* & 3 & + & + & + & - & - & + & - & - & + & + & $\mathrm{a} 1, \mathrm{a} 2, \mathrm{a} 3, \mathrm{a} 4, \mathrm{~b}$ & + & + & + & - & $a, b$ & + \\
\hline FS10001* & 3 & + & + & + & - & - & + & - & - & + & + & $\mathrm{a} 1, \mathrm{a} 2, \mathrm{a} 3, \mathrm{a} 4, \mathrm{~b}$ & + & + & + & - & $a, b$ & + \\
\hline FS10198 & 3 & + & + & + & - & - & + & - & - & + & + & $\mathrm{a} 1, \mathrm{a} 2, \mathrm{a} 3, \mathrm{a} 4, \mathrm{~b}$ & + & + & + & - & $a, b$ & + \\
\hline FS11649 & 3 & + & + & + & - & - & + & - & - & + & + & $\mathrm{a} 1, \mathrm{a} 2, \mathrm{a} 3, \mathrm{a} 4, \mathrm{~b}$ & + & + & + & - & $a, b$ & + \\
\hline FS10040* & 3 & + & + & + & $+^{\mathrm{f}}$ & - & + & - & - & + & + & $\mathrm{a} 1, \mathrm{a} 2, \mathrm{a} 3, \mathrm{a} 4, \mathrm{~b}$ & + & + & + & - & $a, b$ & + \\
\hline FS10211 & 3 & + & + & + & $+^{\mathrm{f}}$ & - & + & - & - & + & + & $\mathrm{a} 1, \mathrm{a} 2, \mathrm{a} 3, \mathrm{a} 4, \mathrm{~b}$ & + & + & + & - & $a, b$ & + \\
\hline FS10216 & 3 & + & + & + & $t^{\mathrm{f}}$ & - & + & - & - & + & + & $\mathrm{a} 1, \mathrm{a} 2, \mathrm{a} 3, \mathrm{a} 4, \mathrm{~b}$ & + & + & + & - & $a, b$ & + \\
\hline FS07024 & 3 & + & + & + & + & - & - & - & - & + & + & $\mathrm{a} 1, \mathrm{a} 2, \mathrm{a} 3, \mathrm{a} 4, \mathrm{~b}$ & + & + & + & - & $a, b$ & + \\
\hline FS09016 & 3 & + & + & + & + & - & - & - & - & + & + & $\mathrm{a} 1, \mathrm{a} 2, \mathrm{a} 3, \mathrm{a} 4, \mathrm{~b}$ & + & + & + & - & $a, b$ & + \\
\hline FS10012 & 3 & + & + & + & + & - & - & - & - & + & + & $\mathrm{a} 1, \mathrm{a} 2, \mathrm{a} 3, \mathrm{a} 4, \mathrm{~b}$ & + & + & + & - & $a, b$ & + \\
\hline FS10053 & 3 & + & + & + & + & - & - & - & - & + & + & $\mathrm{a} 1, \mathrm{a} 2, \mathrm{a} 3, \mathrm{~b}$ & + & + & + & - & $a, b$ & + \\
\hline FS10224 & 3 & + & + & + & + & - & - & - & - & + & + & $\mathrm{a} 1, \mathrm{a} 2, \mathrm{a} 3, \mathrm{a} 4, \mathrm{~b}$ & + & + & + & - & $a, b$ & - \\
\hline FS11527 & 3 & + & + & + & + & - & - & - & - & + & + & $\mathrm{a} 1, \mathrm{a} 2, \mathrm{a} 3, \mathrm{a} 4, \mathrm{~b}$ & + & + & + & - & $a, b$ & + \\
\hline FS09025 & 3 & + & + & + & + & - & $+g$ & - & - & + & + & $\mathrm{a} 1, \mathrm{a} 2, \mathrm{a} 3, \mathrm{a} 4, \mathrm{~b}$ & + & + & + & - & $a, b$ & + \\
\hline FS10099 & 3 & + & + & + & + & - & $+^{g}$ & - & - & + & + & $\mathrm{a} 1, \mathrm{a} 2, \mathrm{a} 3, \mathrm{a} 4, \mathrm{~b}$ & + & + & + & - & $a, b$ & + \\
\hline FS10218 & 3 & + & + & + & + & - & + & - & - & + & + & $\mathrm{a} 1, \mathrm{a} 2, \mathrm{a} 3, \mathrm{~b}$ & + & + & + & - & $a, b$ & + \\
\hline FS10228 & 3 & + & + & + & + & - & + & - & - & + & + & $\mathrm{a} 1, \mathrm{a} 2, \mathrm{a} 3, \mathrm{~b}$ & + & + & + & - & $a, b$ & + \\
\hline FS11597a & 3 & + & + & + & + & - & + & - & - & + & + & $\mathrm{a} 1, \mathrm{a} 2, \mathrm{a} 3, \mathrm{a} 4, \mathrm{~b}$ & - & + & + & - & $a, b$ & + \\
\hline FS11509 & 3 & + & + & + & + & - & + & - & - & + & + & $\mathrm{a} 1, \mathrm{a} 2, \mathrm{a} 3, \mathrm{a} 4, \mathrm{~b}$ & + & - & + & - & $a, b$ & + \\
\hline FS11603b & 3 & + & + & + & + & - & + & - & - & + & + & $\mathrm{a} 1, \mathrm{a} 2, \mathrm{a} 3, \mathrm{a} 4, \mathrm{~b}$ & + & - & + & - & $a, b$ & + \\
\hline FS11608 & 3 & + & + & + & + & - & + & - & - & + & + & $\mathrm{a} 1, \mathrm{a} 2, \mathrm{a} 3, \mathrm{a} 4, \mathrm{~b}$ & + & - & + & tinu & $\begin{array}{l}\mathrm{a}, \mathrm{b} \\
\text { on ne }\end{array}$ & $\begin{array}{c}+ \\
\text { page })\end{array}$ \\
\hline
\end{tabular}

a Fusarium spp. and isolate code. The 11 Fusarium isolates indicated by an asterisk $(*)$ have been previously assessed for their pathogenicity on two sesame cultivars, Yuzhi 11 and Ji 9014, by Qiu et al. (2014).

b Pathogenicity group.

c Pathogenicity of the 69 isolates on sesame cultivars Yuzhi 11 (Yu), Ji 9014 (Ji), and HJ16 (HJ): + indicates highly pathogenic to seedlings of the corresponding sesame cultivar, presenting $50<$ disease index $(\mathrm{DI}) \leq 100$, and - indicates nonpathogenic or weakly pathogenic to the corresponding sesame cultivar, presenting $0 \leq \mathrm{DI} \leq 20$.

d Symbols: + indicates the presence of one secreted-in-xylem (SIX) gene homolog in the corresponding isolate, - indicates the absence of a SIX gene in the corresponding isolate, and single letters indicate the homologs of one F. oxysporum f. sp. sesami SIX gene in the corresponding isolate.

e The $5^{\prime}$ untranslated region of $F$. oxysporum f. sp. sesami SIX8a4 is interrupted by a transposon.

${ }^{\mathrm{f}}$ Coding sequences of $F$. oxysporum f. sp. sesami SIX1 are interrupted by the transposons.

$\mathrm{g}$ Coding sequences of $F$. oxysporum f. sp. sesami SIX3 are interrupted by the transposons. 
comparing the presence and sequence variations of $S I X$ genes between different $F$. oxysporum isolates, $F$. oxysporum f. sp. sesami exhibited a specific combination of SIX genes, which was distinguishable from the $S I X$ gene profiles in other formae speciales screened in this study (Table 3; Supplementary Table S2). In addition, among the $F$. oxysporum f. sp. sesami isolates, $F$. oxysporum f. sp. sesami pathogenicity group 2 was distinguishable from $F$. oxysporum f. sp. sesami pathogenicity groups 1 and 3 by the absence of both SIX8a3 and SIX13b, whereas F. oxysporum f. sp. sesami pathogenicity groups 1 and 3 exhibited a similar profile of SIX genes.

Evolutionary relationship of $S I X$ genes in $F$. oxysporum f. sp. sesami. The phylogenetic trees were constructed for each of 10 SIX genes identified in F. oxysporum f. sp. sesami to further determine the evolutionary relationships of the SIX genes. The results showed that the SIX gene sequence divergence was clearly observed between the different $F$. oxysporum formae speciales, and F. oxysporum f. sp. sesami was also separated from the other formae speciales in the SIX1, SIX3, SIX6, SIX7, SIX10, SIX11, and SIX13 gene trees but not in the $S I X 8, S I X 9$, and $S I X 14$ gene trees owing to the identical SIX gene sequences described above between $F$. oxysporum f. sp. sesami and several other formae speciales (Fig. 3). In addition, the five homologs of F. oxysporum f. sp. sesami $S I X 8$ were clustered into four subclades in the SIX 8 gene tree, while
F. oxysporum f. sp. sesami SIX8al and SIX8a2 was placed in a subclade including SIX8a5 in the nonpathogenic isolates FS10090a and FS10176b and the homologs of SIX8 in f. sp. cubense race 4 isolates (Fig. 3E; Supplementary Fig. S1), and presented more distant evolutionary relationships with one another compared with the SIX8 homologs in other formae speciales. Unlike $F$. oxysporum f. sp. sesami SIX8, the two homologs of F. oxysporum f. sp. sesami SIX13 were sorted into one subclade, and F. oxysporum f. sp. sesami $S I X 13 a$ seemed to be more similar to $F$. oxysporum f. sp. medicaginis SIX13b than to F. oxysporum f. sp. sesami SIX13b (Fig. 3I; Supplementary Fig. S2).

The topologies of the SIX gene trees were further compared with the EF-la tree. F. oxysporum f. sp. sesami and other formae speciales were clustered together in the SIX1, SIX3, SIX10, SIX11, and $S I X 13$ gene trees but were placed into distant clades in the EF- $1 a$ tree (Figs. 2 and 3). For example, F. oxysporum f. sp. sesami presented closer relationships to F. oxysporum f. sp. melonis in the $S I X 1$ gene tree but they were separated into clades I and II in the $E F-1 a$ tree. The results indicate that the SIX gene phylogeny is discordant to the EF-la phylogeny.

Expression profiles of $F$. oxysporum f. sp. sesami SIX genes upon infection with $F$. oxysporum f. sp. sesami. To explore the expression profiles of the $10 F$. oxysporum f. sp. sesami

TABLE 3. (Continued from previous page)

\begin{tabular}{|c|c|c|c|c|c|c|c|c|c|c|c|c|c|c|c|c|c|c|}
\hline \multirow[b]{2}{*}{ Species, code ${ }^{\mathrm{a}}$} & \multirow[b]{2}{*}{$\mathrm{PG}^{\mathrm{b}}$} & \multicolumn{3}{|c|}{ Pathogenicity } & \multicolumn{14}{|c|}{ SIX gene ${ }^{\mathrm{d}}$} \\
\hline & & $\mathrm{Yu}$ & $\mathrm{Ji}$ & $\mathrm{HJ}$ & 1 & 2 & 3 & 4 & 5 & 6 & 7 & $8^{e}$ & 9 & 10 & 11 & 12 & 13 & 14 \\
\hline FS10044* & 3 & + & + & + & + & - & + & - & - & + & + & $\mathrm{a} 1, \mathrm{a} 2, \mathrm{a} 3, \mathrm{a} 4, \mathrm{~b}$ & + & + & + & - & $a, b$ & - \\
\hline FS11702 & 3 & + & + & + & + & - & + & - & - & + & + & $\mathrm{a} 1, \mathrm{a} 2, \mathrm{a} 3, \mathrm{a} 4, \mathrm{~b}$ & + & + & + & - & $a, b$ & - \\
\hline FS08027 & 3 & + & + & + & + & - & + & - & - & + & + & $\mathrm{a} 1, \mathrm{a} 2, \mathrm{a} 3, \mathrm{a} 4, \mathrm{~b}$ & + & + & + & - & $a, b$ & + \\
\hline FS08042 & 3 & + & + & + & + & - & + & - & - & + & + & $\mathrm{a} 1, \mathrm{a} 2, \mathrm{a} 3, \mathrm{a} 4, \mathrm{~b}$ & + & + & + & - & $a, b$ & + \\
\hline FS09012 & 3 & + & + & + & + & - & + & - & - & + & + & $\mathrm{a} 1, \mathrm{a} 2, \mathrm{a} 3, \mathrm{a} 4, \mathrm{~b}$ & + & + & + & - & $a, b$ & + \\
\hline FS09033 & 3 & + & + & + & + & - & + & - & - & + & + & $\mathrm{a} 1, \mathrm{a} 2, \mathrm{a} 3, \mathrm{a} 4, \mathrm{~b}$ & + & + & + & - & $a, b$ & + \\
\hline FS09035 & 3 & + & + & + & + & - & + & - & - & + & + & $\mathrm{a} 1, \mathrm{a} 2, \mathrm{a} 3, \mathrm{a} 4, \mathrm{~b}$ & + & + & + & - & $a, b$ & + \\
\hline FS09037 & 3 & + & + & + & + & - & + & - & - & + & + & $\mathrm{a} 1, \mathrm{a} 2, \mathrm{a} 3, \mathrm{a} 4, \mathrm{~b}$ & + & + & + & - & $a, b$ & + \\
\hline FS09038 & 3 & + & + & + & + & - & + & - & - & + & + & $\mathrm{a} 1, \mathrm{a} 2, \mathrm{a} 3, \mathrm{a} 4, \mathrm{~b}$ & + & + & + & - & $a, b$ & + \\
\hline FS09076 & 3 & + & + & + & + & - & + & - & - & + & + & $\mathrm{a} 1, \mathrm{a} 2, \mathrm{a} 3, \mathrm{a} 4, \mathrm{~b}$ & + & + & + & - & $a, b$ & + \\
\hline FS09077 & 3 & + & + & + & + & - & + & - & - & + & + & $\mathrm{a} 1, \mathrm{a} 2, \mathrm{a} 3, \mathrm{a} 4, \mathrm{~b}$ & + & + & + & - & $a, b$ & + \\
\hline FS09100* & 3 & + & + & + & + & - & + & - & - & + & + & $\mathrm{a} 1, \mathrm{a} 2, \mathrm{a} 3, \mathrm{a} 4, \mathrm{~b}$ & + & + & + & - & $a, b$ & + \\
\hline FS10112 & 3 & + & + & + & + & - & + & - & - & + & + & $\mathrm{a} 1, \mathrm{a} 2, \mathrm{a} 3, \mathrm{a} 4, \mathrm{~b}$ & + & + & + & - & $a, b$ & + \\
\hline FS10173a2 & 3 & + & + & + & + & - & + & - & - & + & + & $\mathrm{a} 1, \mathrm{a} 2, \mathrm{a} 3, \mathrm{a} 4, \mathrm{~b}$ & + & + & + & - & $a, b$ & + \\
\hline FS10195 & 3 & + & + & + & + & - & + & - & - & + & + & $\mathrm{a} 1, \mathrm{a} 2, \mathrm{a} 3, \mathrm{a} 4, \mathrm{~b}$ & + & + & + & - & $a, b$ & + \\
\hline FS11416 & 3 & + & + & + & + & - & + & - & - & + & + & $\mathrm{a} 1, \mathrm{a} 2, \mathrm{a} 3, \mathrm{a} 4, \mathrm{~b}$ & + & + & + & - & $a, b$ & + \\
\hline FS11454a & 3 & + & + & + & + & - & + & - & - & + & + & $\mathrm{a} 1, \mathrm{a} 2, \mathrm{a} 3, \mathrm{a} 4, \mathrm{~b}$ & + & + & + & - & $a, b$ & + \\
\hline FS11473a & 3 & + & + & + & + & - & + & - & - & + & + & $\mathrm{a} 1, \mathrm{a} 2, \mathrm{a} 3, \mathrm{a} 4, \mathrm{~b}$ & + & + & + & - & $a, b$ & + \\
\hline FS11614 & 3 & + & + & + & + & - & + & - & - & + & + & $\mathrm{a} 1, \mathrm{a} 2, \mathrm{a} 3, \mathrm{a} 4, \mathrm{~b}$ & + & + & + & - & $a, b$ & + \\
\hline FS11641 & 3 & + & + & + & + & - & + & - & - & + & + & $\mathrm{a} 1, \mathrm{a} 2, \mathrm{a} 3, \mathrm{a} 4, \mathrm{~b}$ & + & + & + & - & $a, b$ & + \\
\hline FS11710b & 3 & + & + & + & + & - & + & - & - & + & + & $\mathrm{a} 1, \mathrm{a} 2, \mathrm{a} 3, \mathrm{a} 4, \mathrm{~b}$ & + & + & + & - & $a, b$ & + \\
\hline FS11718a & 3 & + & + & + & + & - & + & - & - & + & + & $\mathrm{a} 1, \mathrm{a} 2, \mathrm{a} 3, \mathrm{a} 4, \mathrm{~b}$ & + & + & + & - & $a, b$ & + \\
\hline FS11719a & 3 & + & + & + & + & - & + & - & - & + & + & $\mathrm{a} 1, \mathrm{a} 2, \mathrm{a} 3, \mathrm{a} 4, \mathrm{~b}$ & + & + & + & - & $a, b$ & + \\
\hline FS11719b1 & 3 & + & + & + & + & - & + & - & - & + & + & $\mathrm{a} 1, \mathrm{a} 2, \mathrm{a} 3, \mathrm{a} 4, \mathrm{~b}$ & + & + & + & - & $a, b$ & + \\
\hline \multicolumn{19}{|l|}{ F. oxysporum } \\
\hline FS10090a* & - & - & - & - & - & - & - & - & - & - & - & a5 & - & - & - & - & - & - \\
\hline FS10176b & - & - & - & - & - & - & - & - & - & - & - & a5 & - & - & - & - & - & - \\
\hline FS07008 & - & - & - & - & - & - & - & - & - & - & - & - & - & - & - & - & - & - \\
\hline FS07021 & - & - & - & - & - & - & - & - & - & - & - & - & - & - & - & - & - & - \\
\hline FS09046 & - & - & - & - & - & - & - & - & - & - & - & - & - & - & - & - & - & - \\
\hline FS09078 & - & - & - & - & - & - & - & - & - & - & - & - & - & - & - & - & - & - \\
\hline FS09086* & - & - & - & - & - & - & - & - & - & - & - & - & - & - & - & - & - & - \\
\hline FS10008* & - & - & - & - & - & - & - & - & - & - & - & - & - & - & - & - & - & - \\
\hline FS10047* & - & - & - & - & - & - & - & - & - & - & - & - & - & - & - & - & - & - \\
\hline FS10184b1 & - & - & - & - & - & - & - & - & - & - & - & - & - & - & - & - & - & - \\
\hline FS10201 & - & - & - & - & - & - & - & - & - & - & - & - & - & - & - & - & - & - \\
\hline FS11458 & - & - & - & - & - & - & - & - & - & - & - & - & - & - & - & - & - & - \\
\hline FS11470 & - & - & - & - & - & - & - & - & - & - & - & - & - & - & - & - & - & - \\
\hline FS11476a & - & - & - & - & - & - & - & - & - & - & - & - & - & - & - & - & - & - \\
\hline FS11584a & - & - & - & - & - & - & - & - & - & - & - & - & - & - & - & - & - & - \\
\hline \multicolumn{19}{|l|}{ F. solani } \\
\hline FS07029 & - & - & - & - & - & - & - & - & - & - & - & - & - & - & - & - & - & - \\
\hline FS08030 & - & - & - & - & - & - & - & - & - & - & - & - & - & - & - & - & - & - \\
\hline FS09040 & - & - & - & - & - & - & - & - & - & - & - & - & - & - & - & - & - & - \\
\hline
\end{tabular}


SIX genes identified in this study, the transcriptional levels of all of the F. oxysporum f. sp. sesami SIX gene homologs were evaluated in sesame roots infected by $F$. oxysporum $\mathrm{f}$. sp. sesami pathogenicity group 3 isolate FS08027 using real-time reverse-transcription PCR (Fig. 4). The expression of each F. oxysporum f. sp. sesami SIX gene was not different between microconidia and mycelia cultured in vitro. Compared with that in microconidia, the expression of F. oxysporum f. sp. sesami SIX8a1, SIX8a2, SIX8b, SIX13a, and SIX14 was significantly upregulated at 24 to $168 \mathrm{hpi}$ and F. oxysporum f. sp. sesami SIX7, SIX10, and SIX13b were upregulated at 48 to $168 \mathrm{hpi}$, whereas $F$. oxysporum f. sp. sesami SIX6, SIX9, and SIX11 were upregulated after 72 hpi. Furthermore, F. oxysporum f. sp. sesami SIX6, SIX8a1, SIX8a2, SIX8b, SIX9, SIX10, SIX11, SIX13a, and SIX14 showed more transcript accumulation as compared with $F$. oxysporum f. sp. sesami SIX7 and $S I X 13 b$. In contrast, the low expression level of $F$. oxysporum f. sp. sesami SIXI did not significantly change at any time point, and F. oxysporum f. sp. sesami SIX3, SIX8a3, and SIX8a4 had no transcripts detected in planta during $F$. oxysporum f. sp. sesami infection.

\section{DISCUSSION}

Sesame Fusarium wilt is one of the major problems facing sesame producers in China owing to its economically destructive effects (Jyothi et al. 2011). Current effective control means are involved in the disease prevention prior to infection with pathogenic

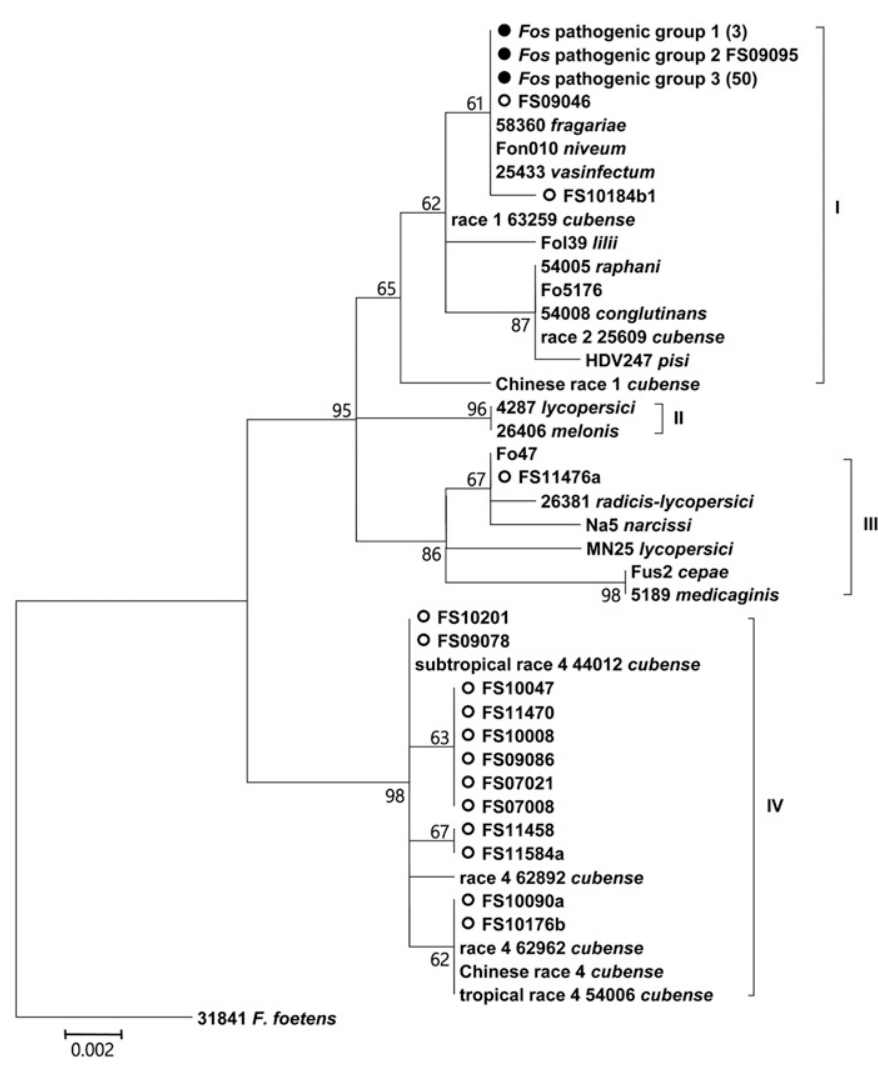

Fig. 2. Maximum-likelihood tree inferred from the translation elongation factor 1a $(E F-1 a)$ gene sequences in Fusarium isolates from sesame and other hosts. Scale bars indicate the number of substitutions per site. Numbers above the branch nodes represent bootstrap values from 1,000 replications. The sequence of EF-1a from Fusarium foetens isolate NRRL 31841 acts as an outgroup to root the tree. The isolates in the same pathogenicity group of $F$. oxysporum f. sp. sesami (Fos) with an identical EF-1a sequence are compressed into a branch, and their number is indicated in parentheses. The $F$. oxysporum f. sp. sesami isolates are indicated by solid black circles and nonpathogenic isolates from sesame are indicated by open circles.
F. oxysporum isolates (Lievens et al. 2008). The ability to reliably identify and distinguish pathogenic $F$. oxysporum isolates from sesame is of key importance for implementation of disease management. In this study, we determined the structure of pathogenic differentiation of $F$. oxysporum f. sp. sesami and demonstrated the correlation between the presence of SIX genes and the pathogenicity of $F$. oxysporum $\mathrm{f}$. sp. sesami on sesame.

To systematically investigate the pathogenicity of $F$. oxysporum isolates from sesame, three sesame cultivars were selected as the differential hosts from more than 500 worldwide sesame germplasms, which were previously assessed for levels of resistance to Fusarium wilt under natural field and greenhouse conditions (data not shown). Based on the significantly different pathogenicity toward the differential cultivars, three pathogenicity groups were defined for $F$. oxysporum f. sp. sesami isolates for the first time. Of three $F$. oxysporum f. sp. sesami pathogenicity groups, the large number of isolates in pathogenicity group 3 with a high level of pathogenicity were the most geographically widespread across China, in contrast to the few isolates in F. oxysporum f. sp. sesami pathogenicity groups 1 and 2 . Therefore, F. oxysporum $\mathrm{f}$. sp. sesami pathogenicity group 3 was indisputably prevalent in past years in China.

Our phylogenetic tree based on $E F-1 a$ sequences divided the FOSC isolates into four clades, which showed that there was considerable genetic diversity between the isolates from sesame. In contrast, the nonpathogenic isolates from sesame were demonstrated to be phylogenetically diverse. F. oxysporum f. sp. sesami isolates were topologically monophyletic, because all of the $F$. oxysporum f. sp. sesami isolates were placed in one clade with an identical $E F-1 a$ sequence. In addition, $F$. oxysporum f. sp. sesami isolates also shared the identical $E F-1 a$ sequence with two nonpathogenic isolates from sesame and another three formae speciales isolates. This suggested that the tree inferred from the $E F$ $l a$ gene failed to distinguish between the pathogenic and nonpathogenic isolates from sesame and between isolates of different formae speciales. In previous reports, poor correlation has been found between sequence variation of housekeeping genes and hostspecific pathogenicity in other $F$. oxysporum isolates (O'Donnell et al. 1998).

Recent findings indicated that pathogenicity in $F$. oxysporum $\mathrm{f}$. sp. lycopersici was conferred by multiple effector genes on a small accessory chromosome (Ma et al. 2010). Among these effector genes, several SIX genes have been further demonstrated to facilitate the pathogenicity of $F$. oxysporum $\mathrm{f}$. sp. lycopersici (Gawehns et al. 2014; Houterman et al. 2009; Ma et al. 2015; Niu et al. 2016; Rep et al. 2004). The hypothesis of the current study was that homologs of SIX genes might exist in F. oxysporum f. sp. sesami with a conserved function, as proposed in other formae speciales (Simbaqueba et al. 2018; Taylor et al. 2016). For the first time, 10 SIX genes were identified in F. oxysporum f. sp. sesami isolates. F. oxysporum f. sp. sesami SIX gene sequences were identical and highly similar within and between $F$. oxysporum f. sp. sesami isolates, respectively, as well as highly conserved with those in other formae speciales. Previously, the high conservation of SIX gene sequences in formae speciales suggested that SIX genes on the accessory chromosome were gained by horizontal gene transfer between F. oxysporum strains (Czislowski et al. 2018; Fraser-Smith et al. 2014; Ma et al. 2010). In our gene trees, further evidence was that there was discordance between the evolutionary relationships of the SIX genes and $E F-1 a$ gene within the FOSC, which supported horizontal gene transfer as the evolutionary origin of $F$. oxysporum f. sp. sesami SIX genes.

The $S I X$ gene profiles in $F$. oxysporum f. sp. sesami isolates were significantly different from the combinations of SIX genes in other formae speciales and absence of SIX genes in the nonpathogenic isolates from sesame. This revealed that there was a clear correlation between the $F$. oxysporum f. sp. sesami SIX gene profile and pathogenicity toward sesame, suggesting that $F$. oxysporum 
f. sp. sesami SIX genes could be used as candidate loci for the molecular differentiation of $F$. oxysporum f. sp. sesami isolates from nonpathogenic isolates and the isolates of other formae speciales. Previously, gene SIX6 was demonstrated to distinguish $F$. oxysporum f. sp. vasinfectum isolates from related colocalized nonpathogenic $F$. oxysporum isolates and from nonnative countries (Chakrabarti et al. 2011). The polymorphisms of SIX3 and the presence of SIX4 were used to distinguish $F$. oxysporum f. sp.
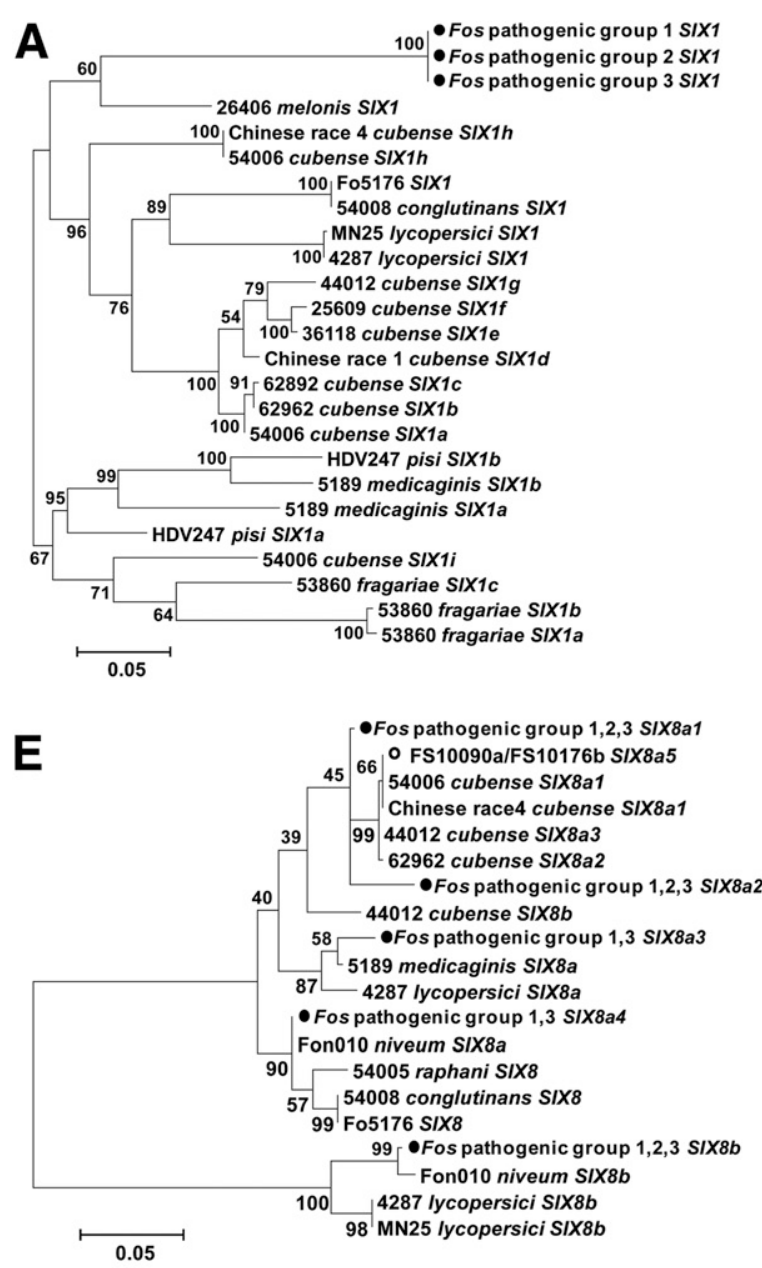

G $100^{\bullet \text { Fos pathogenic group } 1 \text { SIX10 }}$

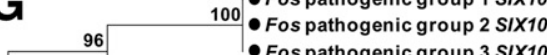

- Fos pathogenic group 3 SIX10

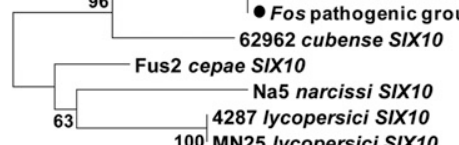

$\stackrel{\longmapsto}{0.005}$

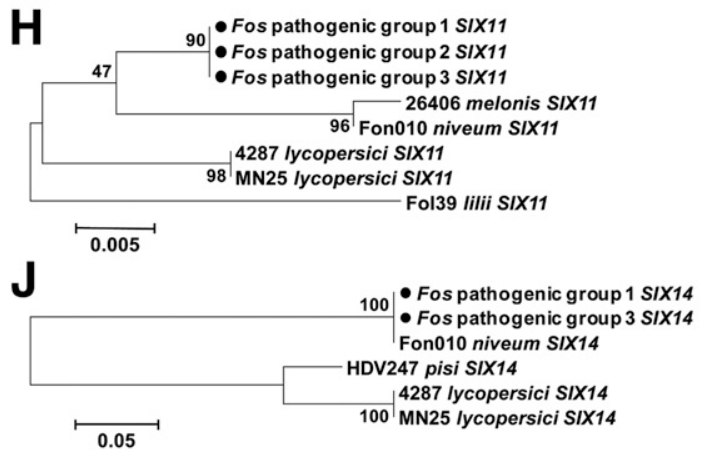

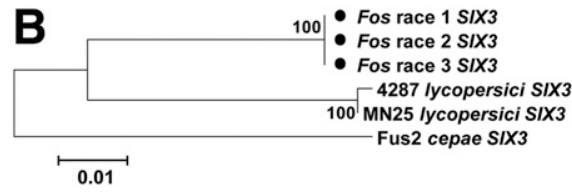

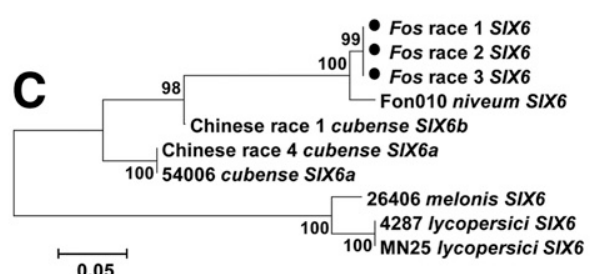

D
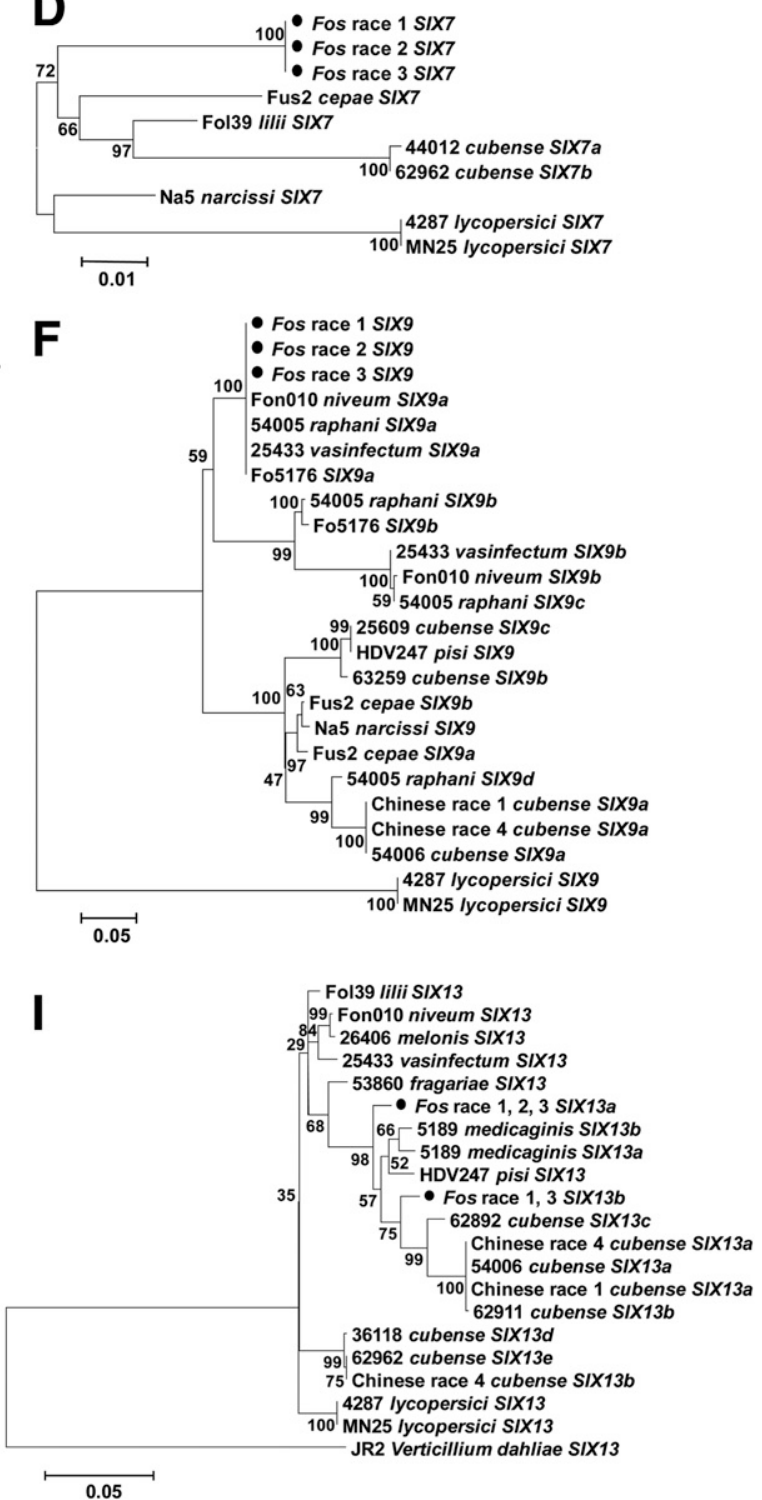

Fig. 3. Maximum-likelihood trees showing the sequences of secreted-in-xylem (SIX) gene sequences in Fusarium oxysporum isolates from sesame, other hosts, and a Verticillium dahliae isolate. A, SIXI; B, SIX3; C, SIX6; D, SIX7; E, SIX8; F, SIX9; G, SIX10; H, SIX11; I, SIX13; and J, SIX14. Isolates in other F. oxysporum and $V$. dahliae used in this study are listed in Supplementary Table S2, and the homologs of SIX genes were obtained for each isolate by a BLAST search from the public nucleotide datasets, including the nucleotide database in GenBank and the selected genome data described in Supplementary Table S1. Isolates in a pathogenicity group of $F$. oxysporum f. sp. sesami (Fos) with an identical sequence of SIX gene homologs are compressed into a branch. The $F$. oxysporum f. sp. sesami isolates are indicated by solid black circles and the nonpathogenic isolate from sesame is indicated by an open circle. 
lycopersici races 1, 2, and 3 (Lievens et al. 2009), and the variation of the SIX gene profile could also reflect the differences in pathogenicity of $F$. oxysporum f. sp. cubense races (Czislowski et al. 2018; FraserSmith et al. 2014). In this study, F. oxysporum f. sp. sesami pathogenicity group 2 was distinguished from $F$. oxysporum $\mathrm{f}$. sp. sesami pathogenicity groups 1 and 3 based on the absence of both $S I X 8 a 3$ and SIX13b but F. oxysporum f. sp. sesami pathogenicity groups 1 and 3 seemed to be indistinguishable owing to their similar SIX gene profiles. Therefore, the suitability of SIX genes to distinguish $F$. oxysporum f. sp. sesami pathogenicity groups should be further assessed in a wider range of $F$. oxysporum f. sp. sesami isolates.

The $F$. oxysporum f. sp. lycopersici race evolution has been reported in a stepwise manner, in which one race evolves from another and the virulence of a race accumulates sequentially in clonal lineages (Biju et al. 2017). Point mutation and gene deletion as well as transposon movement in SIX genes played major roles in the $F$. oxysporum f. sp. lycopersici race evolution by the loss of the
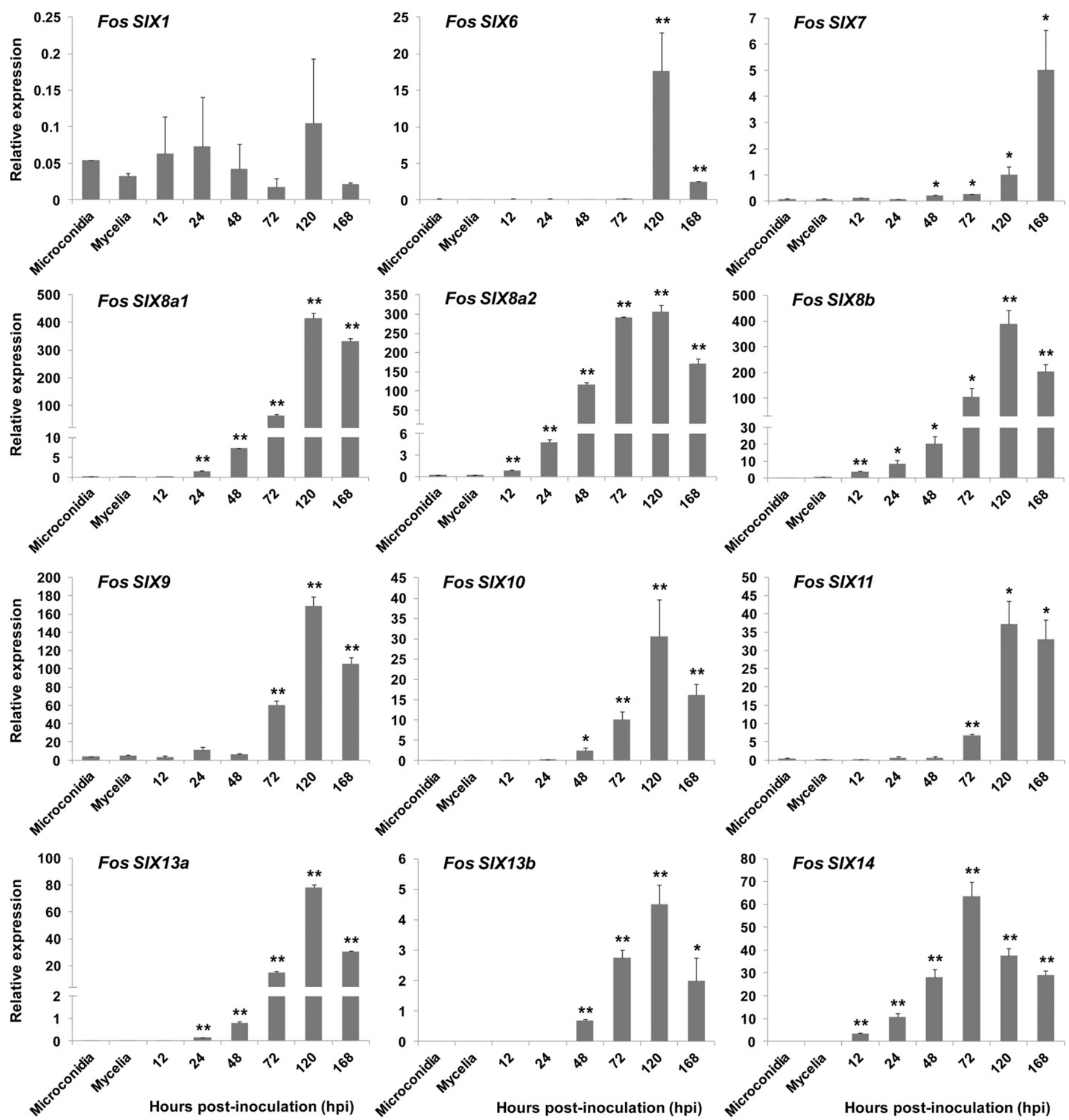

Fig. 4. Expression profiles of the homologs of Fusarium oxysporum f. sp. sesami (Fos) secreted-in-xylem (SIX) genes in sesame roots inoculated with F. oxysporum f. sp. sesami isolate FS08027. F. oxysporum f. sp. sesami $\beta$-tubulin gene was used as a reference gene. Transcriptional levels of $F$. oxysporum f. sp. sesami SIX genes were calculated relative to $\beta$-tubulin. Error bars indicate the standard errors of three biological replications. Asterisks indicate significant differences $(*$ and ** indicate $P<0.05$ and 0.01 , respectively) compared with microconidia using Student's $t$ test. 
avirulence function to evade resistance-gene-mediated resistance in a gene-for-gene relationship (Biju et al. 2017). For F. oxysporum $\mathrm{f}$. sp. sesami isolates, pathogenicity groups 1,2 , and 3 were not only considered to originate from an ancestor because of their monophyletic evolution but also presented gradually higher virulence. Meanwhile, the gene-for-gene relationship was also observed between the differential cultivars and the F. oxysporum f. sp. sesami pathogenicity groups that could be indicated as the $F$. oxysporum $\mathrm{f}$. sp. sesami races, because one dominant resistance gene locus was identified in Yuzhi 11 contributing to resistance to the isolates FS10175 and FS09095, respectively (data not shown). Therefore, the underlying hypothesis was that the $F$. oxysporum f. sp. sesami races had evolved in a similar manner to the $F$. oxysporum $\mathrm{f}$. sp. lycopersici races. In this hypothesis, although the essential virulence genes in $F$. oxysporum $\mathrm{f}$. sp. sesami functioned in hostspecific pathogenicity, the sequence variations of avirulence genes were necessary for the emergence of diverse $F$. oxysporum f. sp. sesami races. Considering the direct correlation between the SIX genes and the specific pathogenicity of F. oxysporum f. sp. sesami, F. oxysporum f. sp. sesami SIX genes were inferred to be recognized as candidates for effector genes. As expected, the homologs of F. oxysporum f. sp. sesami SIX genes were significantly expressed in sesame plants during the $F$. oxysporum f. sp. sesami infection, with the exception of F. oxysporum f. sp. sesami SIX1, SIX3, SIX8a3, and SIX8a4. This supported the idea that most of the F. oxysporum $\mathrm{f} . \mathrm{sp}$. sesami SIX genes played important roles in the virulence genotype. However, the concrete roles of these F. oxysporum f. sp. sesami SIX genes were unknown. More studies such as gene knockout and complementation could be performed in order to reveal the role of SIX genes. In addition, owing to the indistinguishable SIX gene profiles between $F$. oxysporum $\mathrm{f}$. sp. sesami pathogenicity groups 1 and 3, novel effectors should be expected to be found in $F$. oxysporum f. sp. sesami, because the putative effectors $C 5$ and $C R X 1$ were associated with pathogenicity in $F$. oxysporum f. sp. cepae (Taylor et al. 2016).

Overall, the results of the current study subdivided $F$. oxysporum f. sp. sesami isolates into three pathogenicity groups in China. In F. oxysporum f. sp. sesami, the SIX genes were demonstrated to be associated with the specific pathogenicity toward sesame, and can be used as available candidate loci for molecular diagnosis on the basis of pathogenicity. Further studies are required to clearly define the $F$. oxysporum f. sp. sesami races and rigorously validate the hypothesis that SIX genes or novel genes in $F$. oxysporum f. sp. sesami function as effectors to facilitate pathogenicity on sesame and that their sequence variations have resulted in the emergence of diverse $F$. oxysporum f. sp. sesami races by the loss of the avirulence function or other evolutionary pathways.

\section{ACKNOWLEDGMENTS}

We thank Y. Su from Yunnan Academy of Agricultural Sciences for assisting us in the identification and classification of Fusarium isolates.

\section{LITERATURE CITED}

Armstrong, G. M., and Armstrong, J. K. 1981. Formae speciales and races of Fusarium oxysporum causing wilt diseases. Pages 391-399 in: Fusarium: Disease, Biology, and Taxonomy. P. E. Nelson, T. A. Toussoun, and R. J. Cook, eds. The Pennsylvania State University Press, University Park, PA, U.S.A.

Armstrong, J. K., and Armstrong, G. M. 1950. A Fusarium wilt of sesame in United States. Phytopathology 40:785.

Ashri, A. 1998. Sesame breeding. Plant Breed. Rev. 16:179-228.

Baayen, R. P., O’Donnell, K., Bonants, P. J., Cigelnik, E., Kroon, L. P., Roebroeck, E. J., and Waalwijk, C. 2000. Gene genealogies and AFLP analysis in the Fusarium oxysporum complex identify monophyletic and nonmonophyletic formae speciales causing wilt and rot disease. Phytopathology 90:891-900.

Biju, V. C., Fokkens, L., Houterman, P. M., Rep, M., and Cornelissen, B. J. C. 2017. Multiple evolutionary trajectories have led to the emergence of races in Fusarium oxysporum f. sp. lycopersici. Appl. Environ. Microbiol. 83: e02548-16.

Chakrabarti, A., Rep, M., Wang, B., Ashton, A., Dodds, P., and Ellis, J. 2011. Variation in potential effector genes distinguishing Australian and nonAustralian isolates of the cotton wilt pathogen Fusarium oxysporum f. sp. vasinfectum. Plant Pathol. 60:232-243.

Cho, E. K., and Choi, S. H. 1987. Etiology of half stem rot in sesame caused by Fusarium oxysporum. Kor. J. Plant Prot. 26:25-30.

Covey, P. A., Kuwitzky, B., Hanson, M., and Webb, K. M. 2014. Multilocus analysis using putative fungal effectors to describe a population of Fusarium oxysporum from sugar beet. Phytopathology 104:886-896.

Czislowski, E., Fraser-Smith, S., Zander, M., O'Neill, W. T., Meldrum, R. A., Tran-Nguyen, L. T. T., Batley, J., and Aitken, E. A. B. 2018. Investigation of the diversity of effector genes in the banana pathogen, Fusarium oxysporum f. sp. cubense, reveals evidence of horizontal gene transfer. Mol. Plant Pathol. 19:1155-1171.

Epstein, L., Kaur, S., Chang, P. L., Carrasquilla-Garcia, N., Lyu, G., Cook, D. R., Subbarao, K. V., and O'Donnell, K. 2017. Races of the celery pathogen Fusarium oxysporum f. sp. apii are polyphyletic. Phytopathology 107:463-473.

Fraser-Smith, S., Czislowski, E., Meldrum, R. A., Zander, M., O'Neill, W., Balali, G. R., and Aitken, E. A. B. 2014. Sequence variation in the putative effector gene SIX8 facilitates molecular differentiation of Fusarium oxysporum f. sp. cubense. Plant Pathol. 63:1044-1052.

Fuchs, J. G., Moënne-Loccoz, Y., and Défago, G. 1997. Nonpathogenic Fusarium oxysporum strain Fo47 induces resistance to Fusarium wilt in tomato. Plant Dis. 81:492-496.

Gawehns, F., Houterman, P. M., Ichou, F. A., Michielse, C. B., Hijdra, M., Cornelissen, B. J., Rep, M., and Takken, F. L. 2014. The Fusarium oxysporum effector Six6 contributes to virulence and suppresses I-2-mediated cell death. Mol. Plant-Microbe Interact. 27:336-348.

Gordon, T. R., and Martyn, R. D. 1997. The evolutionary biology of Fusarium oxysporum. Annu. Rev. Phytopathol. 35:111-128.

Hogenhout, S. A., van der Hoorn, R. A. L., Terauchi, R., and Kamoun, S. 2009. Emerging concepts in effector biology of plant-associated organisms. Mol. Plant-Microbe Interact. 22:115-122.

Houterman, P. M., Ma, L., Van Ooijen, G., De Vroomen, M. J., Cornelissen, B. J. C., Takken, F. L. W., and Rep, M. 2009. The effector protein Avr2 of the xylem-colonizing fungus Fusarium oxysporum activates the tomato resistance protein I-2 intracellularly. Plant J. 58:970-978.

Houterman, P. M., Speijer, D., Dekker, H. L., de Koster, C. G., Cornelissen, B. J. C., and Rep, M. 2007. The mixed xylem sap proteome of Fusarium oxysporum-infected tomato plants. Mol. Plant Pathol. 8:215-221.

Jyothi, B., Ansari, N. A., Vijay, Y., Anuradha, G., Sarkar, A., Sudhakar, R., and Siddiq, E. A. 2011. Assessment of resistance to Fusarium wilt disease in sesame (Sesamum indicum L.) germplasm. Australas. Plant Pathol. 40: 471-475.

Laurence, M. H., Summerell, B. A., and Liew, E. C. Y. 2015. Fusarium oxysporum f. sp. canariensis: Evidence for horizontal gene transfer of putative pathogenicity genes. Plant Pathol. 64:1068-1075.

Li, D. H., Wang, L. H., Zhang, Y. X., Lv, H. X., Qi, X. Q., Wei, W. L., and Zhang, X. R. 2012. Pathogenic variation and molecular characterization of Fusarium species isolated from wilted sesame in China. Afr. J. Microbiol. Res. 6:149-154.

Li, L. L. 1989. The kinds of diseases and studies in sesame in China. Chin. J. Oil Crop Sci. 1:11-16.

Lievens, B., Houterman, P. M., and Rep, M. 2009. Effector gene screening allows unambiguous identification of Fusarium oxysporum $\mathrm{f}$. sp. lycopersici races and discrimination from other formae speciales. FEMS Microbiol. Lett. 300:201-215.

Lievens, B., Rep, M., and Thomma, B. P. 2008. Recent developments in the molecular discrimination of formae speciales of Fusarium oxysporum. Pest Manage. Sci. 64:781-788.

Ma, L., Houterman, P. M., Gawehns, F., Cao, L., Sillo, F., Richter, H., Clavijo-Ortiz, M. J., Schmidt, S. M., Boeren, S., Vervoort, J., Cornelissen, B. J., Rep, M., and Takken, F. L. 2015. The AVR2-SIX5 gene pair is required to activate $I$-2-mediated immunity in tomato. New Phytol. 208:507-518.

Ma, L.-J., van der Does, H. C., Borkovich, K. A., Coleman, J. J., Daboussi, M.-J., Di Pietro, A., Dufresne, M., Freitag, M., Grabherr, M., Henrissat, B., Houterman, P. M., Kang, S., Shim, W.-B., Woloshuk, C., Xie, X., Xu, J.-R., Antoniw, J., Baker, S. E., Bluhm, B. H., Breakspear, A., Brown, D. W., Butchko, R. A. E., Chapman, S., Coulson, R., Coutinho, P. M., Danchin, E. G. J., Diener, A., Gale, L. R., Gardiner, D. M., Goff, S., Hammond-Kosack, K. E., Hilburn, K., Hua-Van, A., Jonkers, W., Kazan, K., Kodira, C. D., Koehrsen, M., Kumar, L., Lee, Y.-H., Li, L., Manners, J. M., Miranda-Saavedra, D., Mukherjee, M., Park, G., Park, J., Park, S.-Y., Proctor, R. H., Regev, A., Ruiz-Roldan, M. C., Sain, D., Sakthikumar, S., Sykes, S., Schwartz, D. C., Turgeon, B. G., Wapinski, I., Yoder, O., Young, S., Zeng, Q., Zhou, S., Galagan, 
J., Cuomo, C. A., Kistler, H. C., and Rep, M. 2010. Comparative genomics reveals mobile pathogenicity chromosomes in Fusarium. Nature 464:367-373.

Miao, H. M., Chang, S. X., Zhang, H. Y., Huang, J. Y., Duan, Y. H., Qu, W. W. 2019. An evaluation technique of sesame resistance to Fusarium wilt disease at vegetative stage. J. Plant Genet. Resour. doi:10.13430/j.cnki. jpgr.20190428003

Michielse, C. B., and Rep, M. 2009. Pathogen profile update: Fusarium oxysporum. Mol. Plant Pathol. 10:311-324.

Niu, X., Zhao, X., Ling, K. S., Levi, A., Sun, Y., and Fan, M. 2016. The FonSIX6 gene acts as an avirulence effector in the Fusarium oxysporum $\mathrm{f}$. sp. niveum-watermelon pathosystem. Sci. Rep. 6:28146.

O’Donnell, K., Kistler, H. C., Cigelnik, E., and Ploetz, R. C. 1998. Multiple evolutionary origins of the fungus causing Panama disease of banana: Concordant evidence from nuclear and mitochondrial gene genealogies. Proc. Natl. Acad. Sci. U.S.A. 95:2044-2049.

O’Donnell, K., Sutton, D. A., Rinaldi, M. G., Magnon, K. C., Cox, P. A., Revankar, S. G., Sanche, S., Geiser, D. M., Juba, J. H., van Burik, J. A. H., Padhye, A., Anaissie, E. J., Francesconi, A., Walsh, T. J., and Robinson, J. S. 2004. Genetic diversity of human pathogenic members of the Fusarium oxysporum complex inferred from multilocus DNA sequence data and amplified fragment length polymorphism analyses: Evidence for the recent dispersion of a geographically widespread clonal lineage and nosocomial origin. J. Clin. Microbiol. 42:5109-5120.

Pfaffl, M. W. 2001. A new mathematical model for relative quantification in real-time RT-PCR. Nucleic Acids Res. 29:e45.

Qiu, C. P., Zhang, H. Y., Chang, S. X., Wei, L. B., and Miao, H. M. 2014. Laboratory detecting method for pathogenicity of Fusarium oxysporum Schl. f. sp. sesami isolates. Acta Phytopathol. Sin. 44:26-35.

Recorbet, G., Steinberg, C., Olivain, C., Edel, V., Trouvelot, S., Dumas-Gaudot, E., Gianinazzi, S., and Alabouvette, C. 2003. Wanted: Pathogenesis-related marker molecules for Fusarium oxysporum. New Phytol. 159:73-92.

Rep, M., and Kistler, H. C. 2010. The genomic organization of plant pathogenicity in Fusarium species. Curr. Opin. Plant Biol. 13:420-426.

Rep, M., van der Does, H. C., Meijer, M., van Wijk, R., Houterman, P. M., Dekker, H. L., de Koster, C. G., and Cornelissen, B. J. C. 2004. A small, cysteine-rich protein secreted by Fusarium oxysporum during colonization of xylem vessels is required for I-3-mediated resistance in tomato. Mol. Microbiol. 53:1373-1383.
Schmidt, S. M., Houterman, P. M., Schreiver, I., Ma, L., Amyotte, S., Chellappan, B., Boeren, S., Takken, F. L., and Rep, M. 2013. MITEs in the promoters of effector genes allow prediction of novel virulence genes in Fusarium oxysporum. BMC Genomics 14:119.

Schroers, H. J., Baayen, R. P., Meffert, J. P., De Gruyter, J., Hooftman, M., and O'Donnell, K. 2004. Fusarium foetens, a new species pathogenic to $\mathrm{Be}$ gonia elatior hybrids (Begonia $\times$ hiemalis) and the sister taxon of the Fusarium oxysporum species complex. Mycologia 96:393-406.

Simbaqueba, J., Catanzariti, A. M., González, C., and Jones, D. A. 2018. Evidence for horizontal gene transfer and separation of effector recognition from effector function revealed by analysis of effector genes shared between cape-gooseberry- and tomato-infecting formae speciales of Fusarium oxysporum. Mol. Plant Pathol. 19:2302-2318.

Snyder, W. C., and Hansen, H. N. 1940. The species concept in Fusarium. Am. J. Bot. 27:64-67.

Snyder, W. C., and Smith, S. N. 1981. Current status. Pages 25-50 in: Fungal Wilt Diseases of Plants. M. E. Mace, A. A. Bell, and C. H. Beckman, eds. Academic Press, New York, NY, U.S.A.

Su, Y. L., Miao, H. M., Wei, L. B., and Zhang, H. Y. 2012. Study on separation and purification techniques of Fusarium oxysporum in sesame (Sesamum indicum L.). J. Henan Agric. Sci. 41:92-95.

Takken, F., and Rep, M. 2010. The arms race between tomato and Fusarium oxysporum. Mol. Plant Pathol. 11:309-314.

Taylor, A., Vágány, V., Jackson, A. C., Harrison, R. J., Rainoni, A., and Clarkson, J. P. 2016. Identification of pathogenicity-related genes in Fusarium oxysporum f. sp. cepae. Mol. Plant Pathol. 17:1032-1047.

Thatcher, L. F., Gardiner, D. M., Kazan, K., and Manners, J. M. 2012. A highly conserved effector in Fusarium oxysporum is required for full virulence on Arabidopsis. Mol. Plant-Microbe Interact. 25:180-190.

Verma, M. L., Mehta, N., and Sangwan, M. S. 2005. Fungal and bacterial diseases of sesame. Pages 269-303 in: Diseases of Oilseed Crops. G. S. Saharan, N. Mehta, and M. S. Sangwan, eds. B. B. N Printers, New Deli, India.

Williams, A. H., Sharma, M., Thatcher, L. F., Azam, S., Hane, J. K., Sperschneider, J., Kidd, B. N., Anderson, J. P., Ghosh, R., Garg, G., Lichtenzveig, J., Kistler, H. C., Shea, T., Young, S., Buck, S. A., Kamphuis, L. G., Saxena, R., Pande, S., Ma, L. J., Varshney, R. K., and Singh, K. B. 2016. Comparative genomics and prediction of conditionally dispensable sequences in legume-infecting Fusarium oxysporum formae speciales facilitates identification of candidate effectors. BMC Genomics 17:191. 